\title{
PATRONS, MEDIATORS, INSTITUTIONS: THE PARISIAN CAREER OF THE PAINTER VIKTOR MADARÁSZ (1830-1917) IN THE CONTEXT OF SOCIAL CONNECTIONS
}

\begin{abstract}
Viktor Madarász (1830-1917) is considered as one of the defining exponents of "Hungarian national art". Yet, paradoxically, the anointed painter of the so-called Hungarian national romanticism had to go abroad to paint the pictures that would promote the national consciousness in an oppressed country and champion the ideals of Hungarian independence. Madarász lived in the French capital for almost a decade and a half, studying under the academic master Léon Cogniet, exhibiting in the Salon de Paris and becoming acquainted with illustrious members of the Parisian art society. The work that Madarász carried out in France prompts us to investigate the circumstances that influenced his career there. This study aims to take a look at the most productive period in Madarász's career - his Parisian period - in the light of the latest research and with particular emphasis on the works he exhibited at the Salon de Paris. In conveying new information and discussing the social and cultural circumstances of Viktor Madarász's sojourn in Paris, as well as the connections he built up there - with educational establishments, exhibiting institutions, patrons, mediators and other artists -, this paper is intended to provide new insight into the strategies the artist pursued in order to build his career, and thereby to present his Parisian period in a new light.
\end{abstract}

Keywords: Viktor Madarász, Paris, artistic career, social history of art, art institutions, mediators, history painting, Théophile Gautier, Léon Cogniet, private atelier, École des Beaux-Arts, Salon de Paris, Hunyadi

\section{Introduction}

Hungarian art history regards Viktor Madarász (18301917) as one of the defining exponents of "Hungarian national art", which, as a concept, became a central question of Hungarian thinking about art and literature in the nineteenth century, in parallel with the development of Hungarian national identity. ${ }^{2}$ The need to devise a uniquely Hungarian, "national" style of painting was at the forefront of Hungarian art discourse for many decades beginning in the last quarter of the nineteenth century. Since the "Hungarian style" never assumed any absolute form, the main criteria of Hungary's national art became the motif and the subject matter. The "output" of the nation's art was based

\footnotetext{
* Réka Krasznai, curator for 19th-century paintings, Department of Paintings, Hungarian National Gallery, Budapest; e-mail: reka.krasznai@mfab.hu
}

on episodes from the nation's glorious or tragic past, on its people, their character, customs and morals, on the land and its distinctive natural features, and on themes borrowed from Hungarian literature. ${ }^{3}$ In this sense, the history paintings of Viktor Madarász are the very epitome of "national". Yet their style, by virtue of the circumstances in which they were painted, is, nevertheless decidedly international.

Discussion of nineteenth-century Hungarian art as a whole, despite its organic links with the international art scene, only started to break free from the confines of the national discourse in the recent past. Yet it is essential, when dealing with this topic, to look geographically beyond the borders of Hungary itself: a large part of the history of nineteenth-century Hungarian art was played out abroad, in Vienna, Munich and - from the second half of the century - Paris, thanks to the artists who visited those cities, and worked, exhibited, and even settled in them. Hungarian artists were 
drawn to foreign cities primarily because the system of art institutions was far more developed there: opportunities for studying art and exhibiting artworks in Hungary were extremely limited until the last third of the century, so artists travelled to international centres of art in search of advanced training and the chance to make a living. Beginning in the last third of the nineteenth century, Paris gradually replaced Munich as the preferred destination for Hungarian artists, and the French capital played a decisive role in shaping their careers. In 1856, therefore, when Viktor Madarász went to study in Paris, he was very much a pioneer among his compatriots.

Viktor Madarász completed his studies in Paris. He lived in the French capital for almost a decade and a half, studying in the private atelier of the famous academic teacher of painting Léon Cogniet (1794-1880) and at the École des Beaux-Arts. While in Paris, he proudly flaunted his Hungarian patriotic approach: he never became a French citizen (unlike some painters, such as Károly (Charles) Herbsthoffer and Adolf (Adolphe) Weisz, whose names are now all but forgotten in their homeland), he walked in the streets of Paris dressed in traditional Hungarian apparel (Fig. 1), and the works he exhibited at the Salon de Paris - where he was awarded a medal on his very first appearance dealt almost exclusively with Hungarian themes.

The work that Madarász carried out abroad prompts us to investigate the circumstances that influenced his career there. These circumstances belong to the field of the social history of art, and cover a very broad spectrum, starting with art studies, passing through social connections, and reaching as far as the institutions that promoted and sold his works (exhibitions, salons, periodicals). Who were the main mediators between Viktor Madarász and the representatives of the Parisian art scene? Which figures from French artistic, cultural and political life was he in contact with? What was the nature of these relationships? What role did they play in advancing the fortunes of the artist? Last but not least, how did the Hungarian painter make use of his relationship capital as a means of forwarding his career, building up an acknowledged reputation and earning a living? The questions I pose relate to issues that appeared in international research a few decades ago, which skirt the border of art history and social history; they deal with the social status of artists and with various aspects of artistic careers, with particular emphasis on the strategies artists deployed in order to get ahead, and on the networks of contacts that were essential for this.

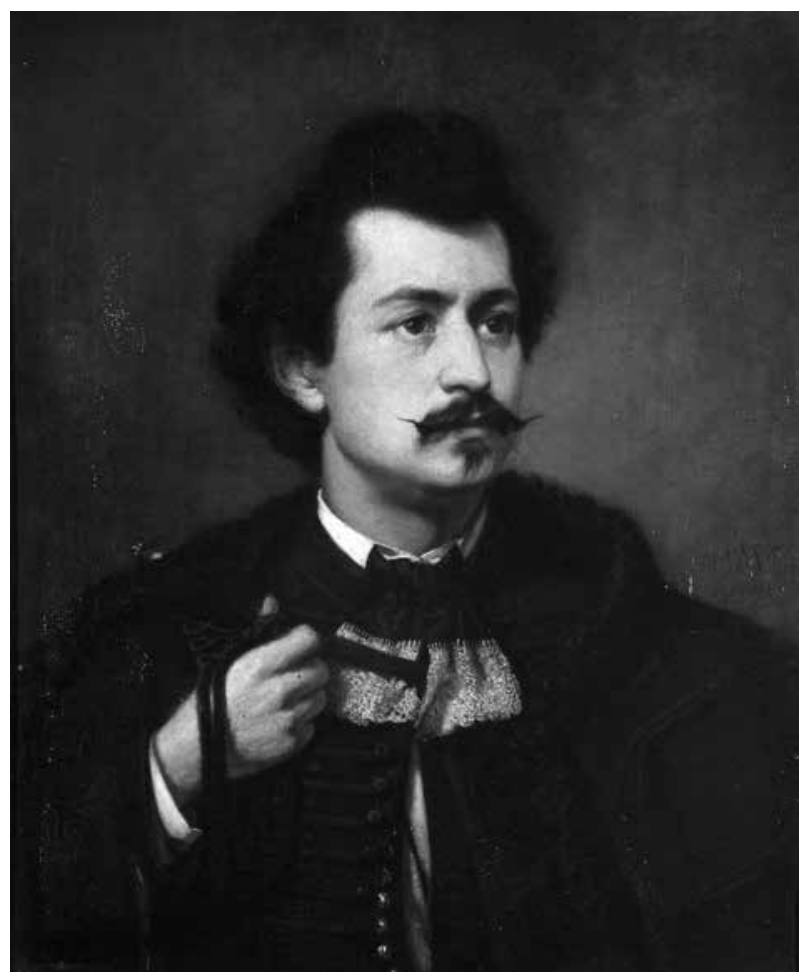

Fig. 1. Viktor Madarász: Self-Portrait, 1863; oil on canvas, $73 \times 59.5 \mathrm{~cm}$; Hungarian National Gallery, Budapest, inv. no. 7585

( Szépmúvészeti Múzeum - Magyar Nemzeti Galéria)

Although this research area has grown extremely popular in recent years in the field of international scholarship, with regard to nineteenth-century Hungarian art, researchers have tackled this topic only sporadically (predominantly concerning Mihály Munkácsy and his art dealer, Charles Sedelmeyer), and references to this subject in Hungarian-language sources are few and far between. ${ }^{4}$

\section{"The Metropolis of Art" - Paris Beckons}

The capital of France became the international centre of art of the modern era, the "métropole de l'art", to use the words of the French poet, author and art critic, Théophile Gautier, writing at the time of the first Exposition Universelle in 1855. Since then the city has been called the "capital of the nineteenth century", ${ }^{5}$ the "capital of modernity", 6 and the "capital of the arts". ${ }^{7}$ Ever since the nineteenth century, Paris has attracted crowds of foreign artists from all over Europe and America. Its magnetic power is based on French culture itself, in particular its centuries-old tradition of fine art, its extensive artistic infrastructure (the Academy, the numerous galleries, the exhibitions and the 
specialist press), and the paradigm shifts in art that have taken place there.

Cultured Hungarians have taken an interest in France for several centuries. ${ }^{8}$ A turning point in this long history came during the Enlightenment and the French Revolution, when France became an exemplary reference point in the eyes of many Hungarians, a role it maintained throughout the nineteenth century. The thoughts of Rousseau attracted a number of followers among Hungarian political thinkers, authors and poets. In the years preceding the Hungarian Revolution of 1848, the leading lights of Hungarian culture enthused about French writers such as Lamartine, Victor Hugo, Dumas and Béranger. During the Bach regime that followed the suppression of the Hungarian Revolution, France, the home of revolutions, remained an encouraging source of inspiration for die-hard Hungarians. Despite the fact that the French reaction to the Hungarian Revolution had not been unanimously positive, ${ }^{9}$ the country welcomed Hungarian refugees and even offered them vital support. Following the Austro-Hungarian Compromise of 1867, these exiles - politicians, freedom fighters, writers and journalists among them - were the first to establish formal relations between newly autonomous Hungary and the Third Republic. Now that the political revolutions had been fought, Hungarians continued to be drawn to the French capital by its modern ideas and innovative art movements.

Throughout the nineteenth century, as Hungary's own artistic institutional system was still underdeveloped (with no art college until 1871, and hardly any opportunities to exhibit paintings), Hungarian artists had to attend art schools and try to build their careers in foreign centres of art, mainly in Vienna at first, which was soon succeeded by Munich. The appeal of Paris grew gradually as the century progressed, so that by the end of the century it had become the primary destination for budding artists. The foremost exhibiting centre in France, the internationally celebrated Salon de Paris, opened its doors to foreign artists as early as 1791 .

\section{The Salon de Paris}

The Salon de Paris was one of the most prestigious art institutions of the nineteenth century. ${ }^{10}$ The exhibitions it held each spring, which brought together the crème de la crème of the contemporary art scene, were among the most widely anticipated art events on the
European calendar. Appearing at the Salon was a milestone in any artist's career, and was one of the most important steps on the way to recognition and appreciation. Young sculptors and painters tried to make their mark on the art world at the Salon, which was the venue where many emerging artists found their first clients. The Salon was the forum where artists could earn the acclaim they deeply desired, where all their hard work could be rewarded; it was also, however, the place where critical opprobrium and public sarcasm resounded most loudly. It was thanks to the Salon shows, in fact, that the profession of critic first came to the fore: here, their words had the power to dictate or question the taste of an era. As expressed by one monographer, Gérard-Georges Lemaire, "As a meeting place of socialites and intellectuals, a stage of cultural life par excellence, this was the pinnacle of the year in Paris, with no shortage of lectures, frivolities and special events." 11

The Salon served a key role in raising the social status of artists. Simply being accepted into the Salon was justification enough for any individual to be regarded as a professional artist. ${ }^{12}$ This marked the first rung on the ladder towards social recognition, and not only in the case of French artists. Works of art were submitted to the Salon de Paris from all over Europe by artists who hoped they might earn plaudits or even prizes. For foreign artists, the Salon was a reference that could define their entire careers. To borrow a phrase from Gérard Monnier, in the nineteenth century, the Salon "signified an obligatory stage on the path towards an artist's social success". ${ }^{13}$

The significance of the Salon de Paris was also widely recognised in Hungary. In 1879, one of Hungary's Sunday papers published a particularly interesting article:

First place among the annual exhibitions of art is occupied by the Parisian "Salon". Everything beautiful and exceptional produced during the previous year with the brush or chisel of a French artist, or at least one living in France, is sent to this show, and if an artist's work is deemed worthy of exhibiting, this is a source of pride. For the judges keep a strict watch over the good reputation of the "Salon", and are careful not to accept anything that seems shoddy or that could lower the standard of the exhibition. For this reason, no matter how famous a painter may be, he never omits to mention if his painting was exhibited at the "Salon". This is commendation in itself, and proof of an 
artistic product. This "Salon" is the great bazaar of the fine arts, where a true talent has the chance to shine, to fight for his name as an artist, and to earn admiration for his art and demand for his works. Nearly all of the latest works by Mihály Munkácsy gained their world renown at the "Salon". ${ }^{14}$

This report, which is interesting for a number of reasons, is one of the rare contemporary Hungarian-language sources that not only write about the Salon de Paris, but also refer to it as the most outstanding international exhibition of the year. It informs the reader about the acclaim that accrues simply from exhibiting at the Salon, and also about how important the Salon is for an artist's reputation and career. At the same time - despite describing the Salon as a "bazaar", a term commonly used by contemporary French critics $^{15}$ the author of the article considered the exhibition to be of a uniformly high standard, although the quantity of works displayed stood in inverse proportion to their quality. Several thousand works were exhibited each year, many of which were downright mediocre, designed to please petit bourgeois taste and to satisfy the art market. It is likely, however, that the Hungarian author was blinded towards these deficiencies by the prestige that the Salon could confer, particularly with regard to Munkácsy, the Hungarian painter who "became world famous". Tellingly, a similar report from 1881, published in the same paper, about the Bucharest Salon, points out the weaker quality of the works on display and comments that "of course, it is not the Parisian Salon." ${ }^{16}$ This statement also confirms that the Salon de Paris was the non plus ultra of exhibitions, enjoying extraordinary prestige in the Hungarian public consciousness, especially among artists themselves.

\section{"Our Friends, the Enemies" - Foreign Artists at the Salon de Paris}

Until the end of the eighteenth century, only French members of the French Academy were permitted to exhibit at the Salon du Louvre, but in 1791 the Salon de Paris opened up to international artists, ${ }^{17}$ as long as their works passed the scrutiny of the jury. However, it was not until 1852 that the catalogues actually began to provide information about the nationality of the artists exhibiting at the Salon, for this was when the artists' places of birth (and the names of their teachers) were first included. Works by foreign artists made up a significant proportion of exhibits at the
Salon, rising from around 15\% of all paintings in the 1850 s to around $20 \%$ soon afterwards, when the figure stabilised until the end of the 1880s. ${ }^{18}$ This means that roughly one in five paintings at the Salon exhibitions was the work of a foreign artist.

At the same time, as has been pointed out by Laurent Cazès, an authority on the subject, ${ }^{19}$ the definition of "foreign" in the nineteenth-century system of French art can be extremely problematic, since the majority of exhibitors at the Salon were residents of Paris. If an artist studied in Paris, exhibited at the Salon, perhaps won a prize or an order of merit, or had a work purchased by the French state, then to all intents and purposes that artist was regarded as French, and this enabled him to forge a career in France. This phenomenon was alluded to by some critics whenever the jury was deemed to have been excessively lenient towards one particular foreign artist or another. ${ }^{20}$

According to Cazès, in 1864, when Théophile Thore drew attention to the fact that the Latin word hostis could mean both "enemy" and "guest", he coined a phrase that summed up the French ambiguity towards artists from abroad: "nos amis les ennemis" (our friends, the enemies). ${ }^{21}$ From the point of view of public administration, the presence of foreign artists was highly desirable, for they enriched the annual Salons with a European aura whilst simultaneously consolidating French hegemony in the arts. This was surely the reason why the jury that decided which works could be exhibited sometimes behaved generously towards foreign artists. At one Salon, 85\% of the works submitted by foreign artists were accepted into the exhibition. ${ }^{22}$ In a speech he delivered at the Salon in 1861, Count Émilien de Nieuwerkerke, state superintendent of the fine arts (and therefore of the Salon de Paris as well), praised its cosmopolitan make-up:

Every city, every nation, sends their painters and sculptors here, as though to a general competition. Marbles and paintings arrive from every continent. They want them to be seen and compared. They want to fight for the prizes that France bestows, which, as a result of their honest impartiality, are never denied to talent, whichever nationality it comes from. They come in crowds. They share our galleries, where it is natural for them to find their place. They augment our catalogue, which has now become a general catalogue of works of art, and then they return home to bear witness that the centre of universal art is here in Paris. ${ }^{23}$ 
Writing about the 1865 Salon, however, the noted French critic Maxime du Camp voiced fears that foreign artists may be jeopardising the supremacy and leading role of French art:

...we are being overrun by foreigners, who are making some worrying progress, because they threaten to consign us to the second or even to the third rate. Our national self-esteem, which is often more excessive than justified, leads us to regard artists who live and exhibit in France as French; this is a mistake, and if we were to do a proper reckoning, we would perhaps be extremely surprised, and a little humiliated, to realise that the Swiss, the Germans and the Belgians alone occupy a considerable place in our exhibitions. ${ }^{24}$

The Salon exhibitions featured thousands of artworks, so foreign artists often exploited their nationality in order to stand out from the crowd. The "exotic" was also present in the themes and characteristics of Hungarian painters, and this influenced the way Hungarian art was viewed to such an extent that it was eventually expected of them. At the same time, however, the exotic had to be reconciled with the codes and values that were integral to both salon painting and French taste. By following this dual system of demands, a painter could escape vilification from the critics and win over the viewing public. The exotic was therefore manifested primarily in the subject matter, while the style (the touche, as it was known at the time) complied with what the French were accustomed to.

\section{Hungarian Painters at the Salon de Paris}

Hungarian painters were drawn to the Salon de Paris from the second half of the nineteenth century onwards. Art history has traditionally placed Viktor Madarász at the head of the line, while discussion of the topic is usually limited to a few names and a few iconic success stories (Viktor Madarász, Mihály Munkácsy). ${ }^{25}$ Research carried out in venues in Paris in the recent past, however, have enriched our knowledge and clarified certain details with a wealth of new data. ${ }^{26}$

The Hungarian painters who exhibited at the Salon de Paris were made up of a mixed bunch: some simply dispatched their paintings to the Salon, while others featured in the shows having completed their studies in the French capital. Paris was just a stop-off for a few artists, while for others the city became their home, with some staying a rather long time. The earliest exhibitor at the Salon de Paris who can demonstrably be regarded as Hungarian was Károly Herbsthoffer (in 1846). ${ }^{27}$ Prior to this we only have knowledge of painters who came from or later settled in Hungary: the Austrian Ágoston (August) Canzi, who later lived in Pest, exhibited at the annual shows in Paris for eight years on the trot beginning in 1833, while Károly Eduárd (Charles Édouard) Boutibonne (1816-1897), who was born in Pest to French parents, made the first of many regular contributions to the Salon in 1837. It cannot be ruled out that Hungarian painters submitted works to the Salon even earlier than this, but if they did, their paintings must have been rejected.

Between 1852 and 1880, nineteen Hungarian painters exhibited a total of 120 works at the Salon de Paris. ${ }^{28}$ Each year, Hungarian artists had to compete with around a thousand rivals, from France and abroad, and their works somehow had to stand out from an overwhelming mass of some two to three thousand paintings. Bearing this in mind, every medal, diploma or positive review counts as an impressive achievement, and during the period in question, Hungarians were rewarded with seven prizes. It has long been claimed that Madarász was the first Hungarian to make a name for himself at the Salon, although this shall be re-examined in the light of recent research. Before Madarász, Károly Herbsthoffer was awarded a certificate of merit (mention honourable) at the Salon in 1859,29 when his name was also mentioned in reviews. The belief that the jury honoured Madarász with a gold medal in 1861 also needs to be reconsidered. ${ }^{30}$ Madarász in fact won a third-class medal (médaille de $3^{e}$ classe), ${ }^{31}$ which was though indeed made of gold (Fig. 2) ${ }^{32}$ This does not in any way detract from the value of the prize, for even to win a third-class medal at the Salon de Paris was an admirable feat.

\section{Madarász on the International Stage of History Painting}

In the second half of the nineteenth century, the movement of national romanticism ${ }^{33}$ - Viktor Madarász being one of its main representatives - was dedicated to reinforcing Hungarians' national consciousness through the evocation of tragic and heroic episodes from Hungary's history. Most members of the painter's family had been revolutionaries, and at the age of eighteen Viktor Madarász himself had played a part in the Revolution of 1848-1849, reaching the rank of major. This experience had a fundamental influence 

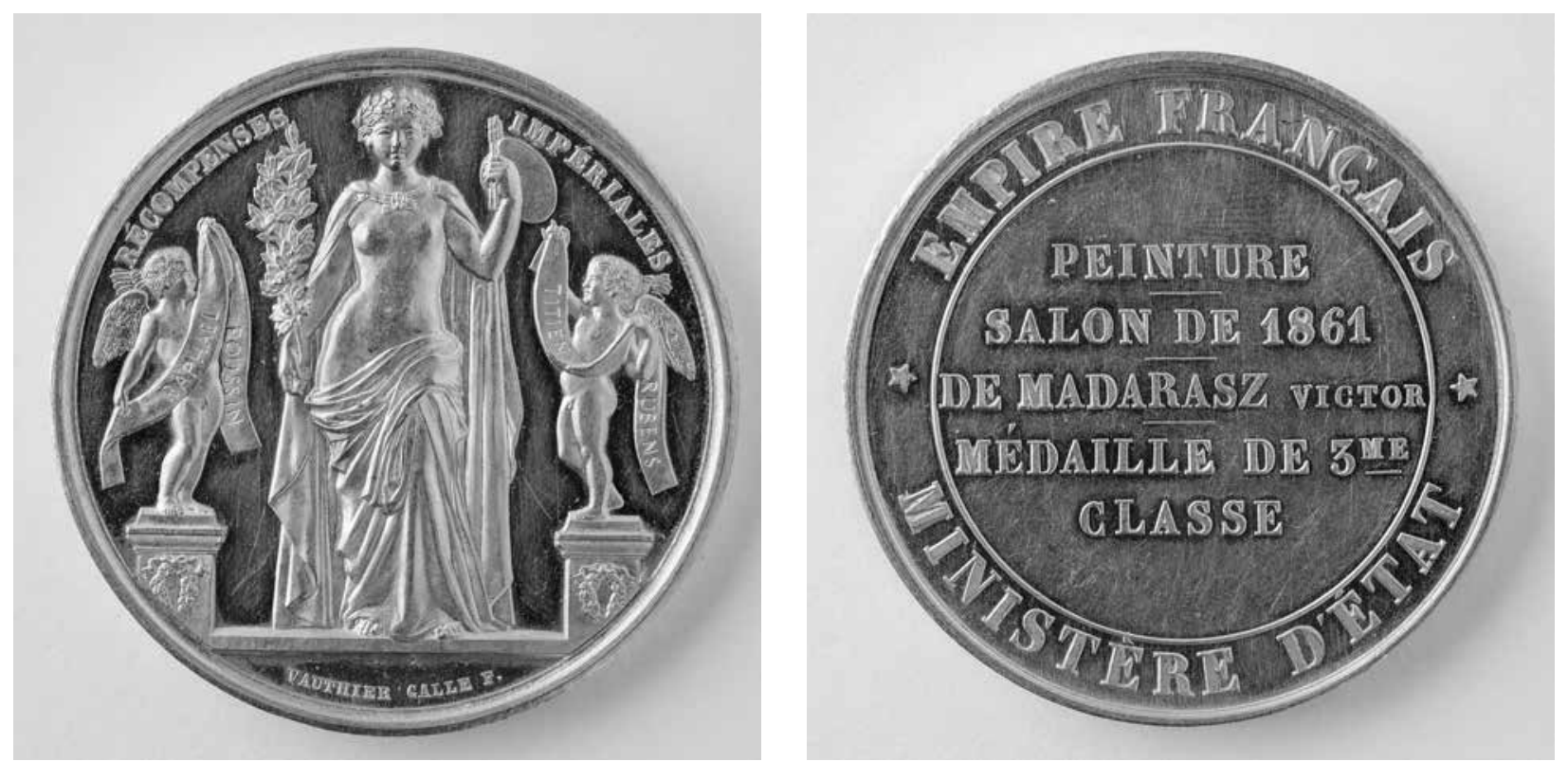

Fig. 2. Medal awarded to Viktor Madarász at the Salon de Paris in 1861; gold, $\varnothing 44 \mathrm{~mm}$; private collection

on his art, which he devoted to the revolutionary ideas of national independence. His great historical works may have recalled events from the distant past, but each of them also concealed a symbolic reference to or message about the political situation at the time - this was one of the factors that ensured their instant success and popularity in the artist's homeland.

History painting in general gained a new lease of life in the mid-nineteenth century. As summarised by Stephen Bann in an essay in the catalogue for the exhibition The Invention of the Past, ${ }^{34}$ large-format history painting is inseparable from the name of Paul Delaroche $^{35}$ (1797-1856), the Frenchman who laid the foundations for this new genre: ${ }^{36}$

[his] primary aim was simply to expand the themes of history painting beyond those of classical antiquity and the Bible. [...] Later, many paintings [...] appeared in Central and Western Europe [...], which reveal the profound influence of history painting, which flourished until the third quarter of the nineteenth century. The genre, which later became widely disseminated in the form of high quality prints and copies, reflected people's desire to obtain a better understanding of history in an age when nationalism was growing ever more widespread and uprisings were not uncommon. ${ }^{37}$

Historical themes were unquestionably extremely well liked among the general public. As Stéphane Paccoud notes, "History paintings, though received by critics with partial reservations, were highly appreciated by visitors to exhibitions". ${ }^{38}$ As an example he points to the stupendous audience success at the Salon de Paris of The Last Honours Paid to Counts Egmont and Horn by Louis Gallait. ${ }^{39}$ Clearly, the ouvre of Viktor Madarász was perfectly in line with the new direction of history painting.

Madarász followed the typical path taken by most of his fellow Hungarian artists in that most of his studies were pursued abroad. He began his career alongside Gusztáv Pósa (1825-1884), who studied at the Munich Academy of Fine Arts. After this, between 1853 and 1856, Madarász went to Vienna, initially enrolling at the Academy of Fine Arts before training himself further in the studio of Ferdinand Georg Waldmüller (1793-1865). In Vienna he painted his first history painting, titled Kuruc and Labanc (Fig. 3), ${ }^{40}$ an allegory of the conflict between the Habsburgs and their opponents. The work was executed during the period of neo-absolutism, replete with political oppression and censorship, so in Hungary, when it was displayed at the Pest Art Society, it was known as Two Brothers and Biography from the Past of Transylvania. The painting was widely reviewed in the press, generating such interest that its future became a matter of public discourse and subject to the art patronage that typified this period: the Pest Art Society supported the purchase of the work by drawing lots among its sponsor members. The enormous canvas thus ended up in the possession of a citizen from the town of Gyöngyös for the remarkably low sum of 350 forints. ${ }^{41}$ 
Léon Cogniet and the École des Beaux-Arts in Paris

Viktor Madarász moved to Paris in 1856 in order to continue his painting studies at the École des BeauxArts. In the nineteenth century, the French capital was not only one of the main centres of art but also a magnet for people who wanted to learn. According to the Hungarian art writer Zsigmond Ormós from the time, "living art and brilliant technique are derived in the field of history painting from Parisian studios alone". ${ }^{42}$ Great masters such as Antoine-Jean Gros (1771-1835), Jean-Auguste-Dominique Ingres (1780-1867), Paul Delaroche (1797-1856), and later François Édouard Picot (1786-1868) and Léon Cogniet (Fig. 4), attracted students to Paris from all over France and every corner of Europe. This part of Madarász's life has not been very deeply discussed before in Hungarian art history writing. The two monographs of the artist (published in $1941^{43}$ and $1954^{44}$ ) mention only that he moved to Paris, attended the École des Beaux-Arts, where he studied in the atelier of the French romantic master Léon Cogniet (Fig. 5), before quitting the school (being dissatisfied with "official" training) in order to carry on in the "private academy" of the very same person. There, he more or less made himself at home. According to a later account, "[a]t Cogniet's, however, he felt good; the old master had a greater sense of the spirit of the age, and as he distanced himself from the academies, he was happy to see in his pupils the ebullience of youthful energy and élan, regardless of how strictly he demanded serious study". ${ }^{45}$ What was the difference, one may wonder, between Cogniet's teaching at the École and the methods he employed in his "private academy"?

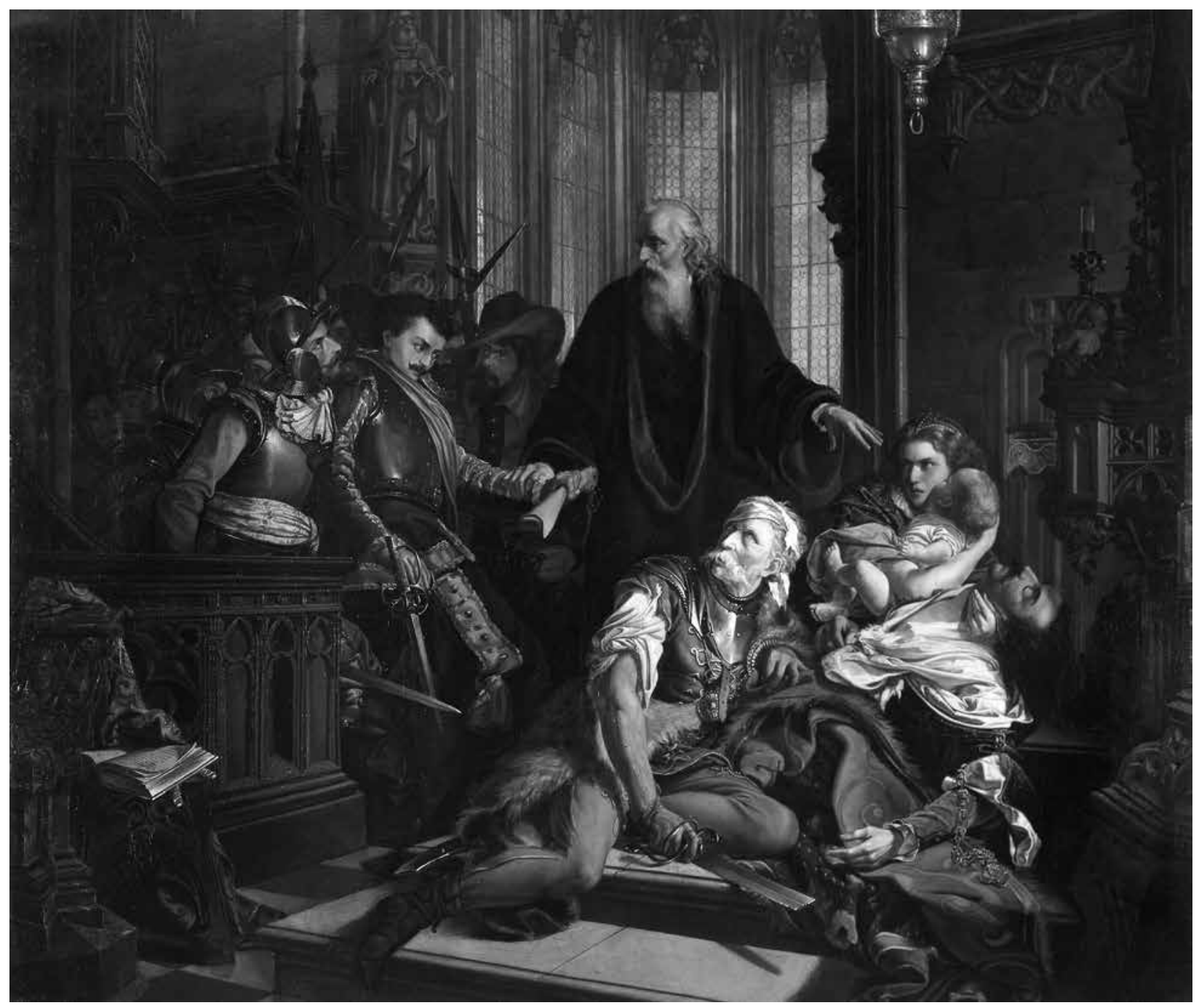

Fig. 3. Viktor Madarász: Kuruc and Labanc, 1855; oil on canvas, $256 \times 300 \mathrm{~cm}$;

owned by the Herend Porcelain Manufactory, presently on longterm loan to the Hungarian National Gallery, Budapest, inv. no. LU 2002.18 (@ Herendi Porcelánmanufaktúra Zrt.) 


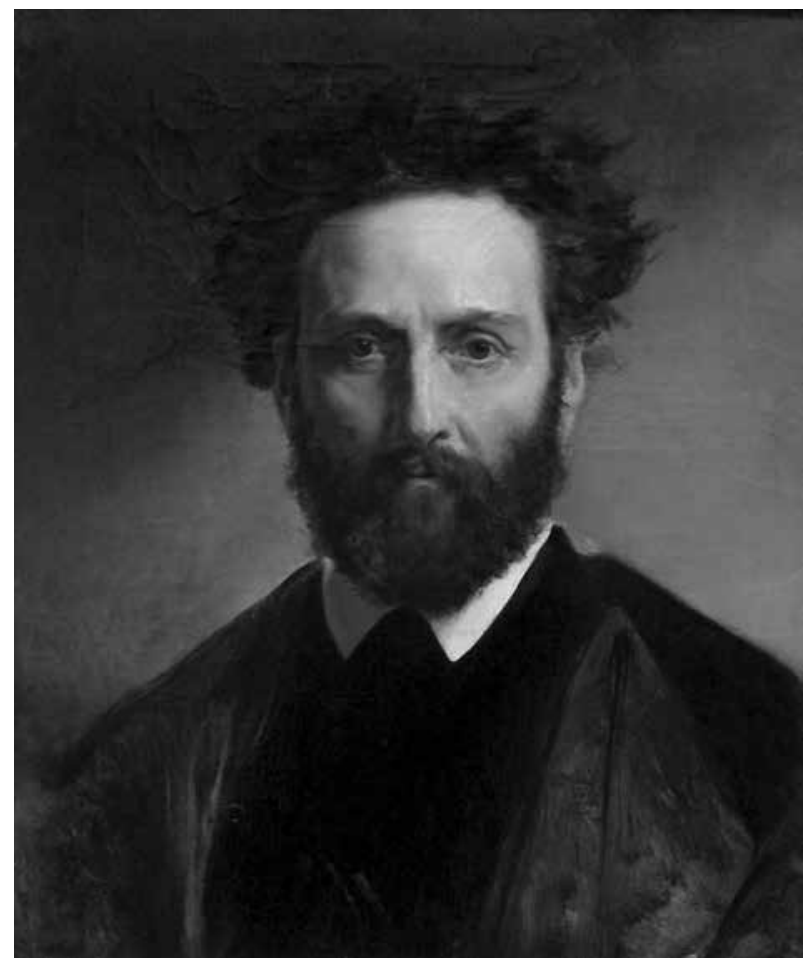

Fig. 4. Léon Cogniet: Self-Portrait, around 1840; oil on canvas, $56.5 \times 46.5 \mathrm{~cm}$; Orléans,

Musée des Beaux-Arts, inv. no. 1038 ( François Lauginie)

The way in which art was taught in France when Madarász was a student ${ }^{46}$ is described in detail in a monograph. ${ }^{47}$ Firstly, it is important to note that the École was not open to beginners: the entrance exam could only be taken by those who had accomplished basic training in drawing, that is, those who could draw a nude. Moreover, the school developed only one aspect of artistic skill, namely the ability to draw. Painting techniques and other methods of the trade had to be picked up in the ateliers privés that were usually led by prominent artists. The true appeal of the École lay in its potential for preparing students to compete for the coveted scholarship, the Prix de Rome. There were undoubtedly additional benefits as well, in that students had free access to live models and could make use of the institution's rich collection of artworks. Young artists were also motivated by the idea of being taught by the school's famous teachers and by the prestige itself: merely being a student at the École des Beaux-Arts in Paris was a letter of recommendation for any aspiring artist.

Teaching at the École was divided into three sections: (1) everyday drawing studies carried out in the studio were supplemented with (2) special courses (anatomy, perspective, history and antiquity), and pupils could then try out their skills at (3) competitive examinations, where to win a medal was also a major accomplishment. These examinations were trial runs for the greatest competition of all, the Prix de Rome. Not every competitive examination was compulsory, however; the right to study at the school depended on an entrance exam, which was taken every half year and was the prerequisite for official registration. When preparing for the entrance exam, however, young artists had to seek help in the private ateliers.

There were no tuition fees at the École des BeauxArts in Paris, and the institution was open to everyone who proved to have the basic drawing skills. If the school had enough capacity, courses on general theory could even be attended by those who were not registered. To register, one had to produce proof of one's date of birth (the upper age limit was 30) and a letter of consent signed by one of the school's professors. In order to take part in practical lessons, however, held in studios where space was limited, pupils had to pass a test known as the concours des places. This was effectively an entrance exam, held every March and September, the results of which determined which student would study under which master. If the applicant was not a resident of Paris, evidence also had to be provided both of good conduct and of the (advanced level) studies undertaken to date.

The archives of the École des Beaux-Arts in Paris preserve the documents of the artists who studied there in the nineteenth century. The list of registered students reveals that Madarász was the sole Hungarian at the school in that period. His dossier ${ }^{48}$ includes a birth certificate, issued by the Austrian embassy on 13 March 1857, and a letter signed by Léon Cogniet. In the letter, dated 13 April 1857, the master vouches for the young man's good character (certificate of good conduct), advises that he can sit the concours de places (he has the requisite level of attainment), and asks the professors to "consider him as a candidate for a place as a student" (recommendation of enrolment). This, therefore, is the commendation from Cogniet that earned Madarász the right to sit the entrance exam to the École des Beaux-Arts. In order to be admitted to the institution, however, the young artist had to perform well at the particularly rigorous entrance exam. This letter of commendation proves that Cogniet already knew Madarász quite well; the Hungarian had most certainly been a private student in the master's atelier to prepare for the concours de places, which traditionally consisted of six two-hour sessions of drawing nudes. When Madarász was accepted at the École, there was no question that he would be placed 


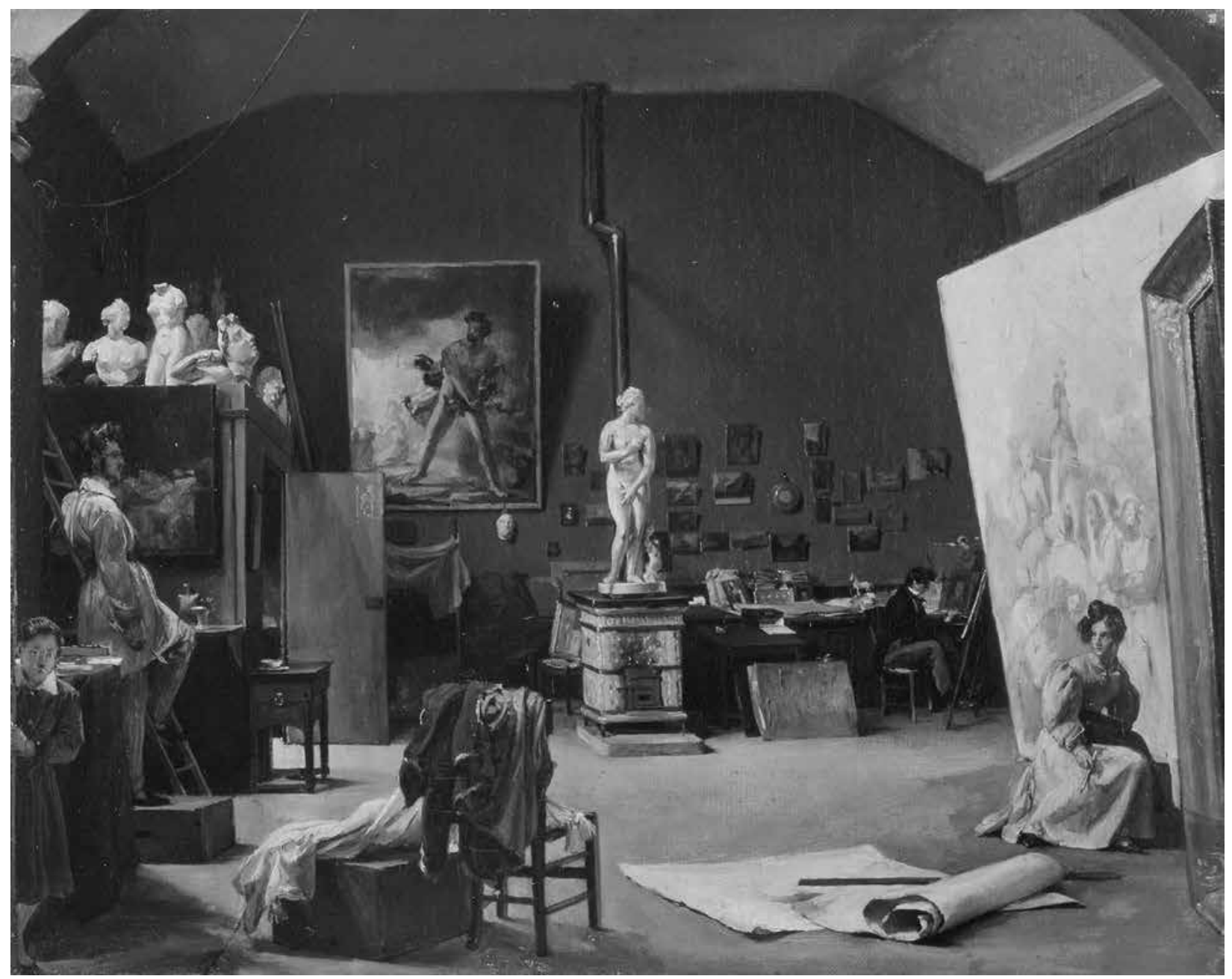

Fig. 5. Marie-Amélie Cogniet: The Studio of Léon Cogniet in 1831, 1831;

oil on canvas, $33 \times 40.2$ cm; Orléans, Musée des Beaux-Arts, inv. no. 296 ( François Lauginie)

in Cogniet's class. Private schools, similarly to the École des Beaux-Arts, based their teaching on competitions: pupils were expected to pit their skills against one another in order to earn their master's approval as well as the concomitant prizes. Madarász won a medal in Cogniet's atelier in 1857 in the concours de la tête d'expression (competition for the expressive head), and the following year he won a prize in linear perspective at the École. ${ }^{49}$

Despite its prestige, the École was not the apogee of training as an artist, for it concentrated only on polishing one's skill at drawing. The school provided students an opportunity to practise drawing from the live model and from plaster casts of ancient statues under the eye of an illustrious professor, and all for free. Twelve hours were set aside for each drawing, so during a semester, a student would make on average eight nude studies from life and eight studies from plaster casts. The Hungarian National Gallery owns several study drawings ${ }^{50}$ by Viktor Madarász, which probably have been made during his time at the École (Fig. 6): this idea is supported by their papers' French watermark (Michallet). ${ }^{51}$ When it came to perfecting his technique as a painter, Madarász had to search outside the school for a private teacher, and this is probably what led him (back) to Cogniet's atelier.

Private ateliers to a large extent imitated the teaching practice of the École, with great emphasis placed on drawing after the live model and after plaster casts - after all, one objective was to prepare students for entrance exams and competitions. Their main function, however, was to supplement the school by offering practical tuition in painting (or sculpture). The pupils, especially the beginners, learnt a great deal from each other and from their more experienced comrades. The master himself would only visit the students in his studio once or twice a week, commenting on and correcting their works in progress, and per- 


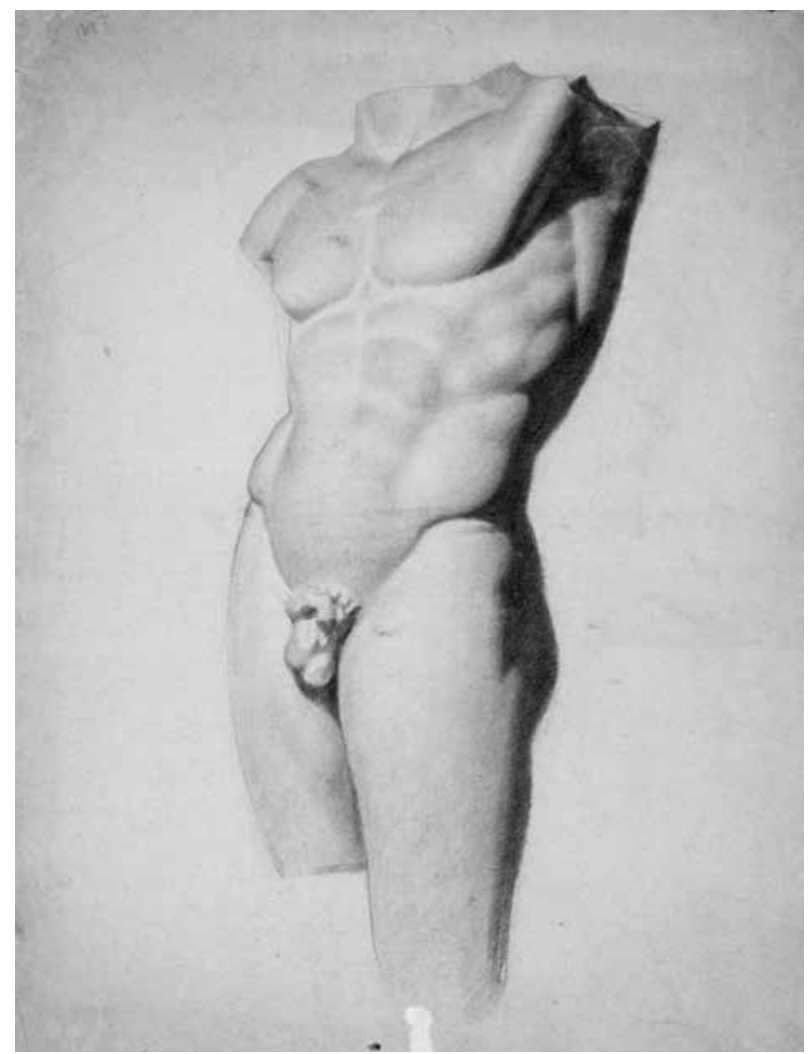

Fig. 6. Viktor Madarász: Study of a Torso, between 1856 and 1859; pencil and charcoal on paper, $460 \times 330 \mathrm{~mm}$; Hungarian National Gallery, Budapest, inv. no. F 71.91/1 (@ Szépmúvészeti Múzeum - Magyar Nemzeti Galéria)

haps offering some of his own reflections about art. Very often, the master - e. g. Léon Cogniet - who had spent the morning advising pupils in his own studio would turn up at the École in the afternoon, in his capacity as professor, and quite likely go around correcting the work of the very same set of students.

Léon Cogniet represented the type of romantic history painting epitomised by Paul Delaroche. He derived his subjects from past times, while his execution and technique remained eternally traditional. He completed his studies in 1812 at the École des BeauxArts in Paris, studying in the atelier of the free-minded Pierre-Narcisse Guérin (1774-1833), who taught some of the most famous romantic artists, including Eugène Delacroix (1798-1863) and Théodore Géricault (1791-1824). In 1817, at the age of 23, Cogniet won the Prix de Rome, which enabled him to spend five years in Rome, and which represented, in a way, official recognition of Guérin's teaching methods and of the new trends in general.

The neo-classical painting that Cogniet had completed two years earlier, in 1815, which earned the young artist the second prize in the Prix de Rome, is now in the museum in Orléans. ${ }^{52}$ The subject - Briseis mourning Patroclus, an episode from the Iliad - brings to life the age of the Trojan Wars (Fig. 7). The painting emulates the works of Jacques-Louis David (17481825) in its intense theatricality, and is focused on the moment of climactic tension when Achilles steps forward and vows to avenge the death of his friend. Achilles is the sole character in the painting whom Cogniet has portrayed as an heroic nude, which accentuates his figure among the others, as does the emphatic use of the brick-red pigment that is so characteristic of David's work. The mourning of the fallen hero is a rich pictorial topos that recurs in the most diverse interpretations throughout European history painting, in an age when the continent was beset by revolution after revolution. It is interesting to note that when Madarász first exhibited at the Salon de Paris, as a student of Cogniet's, he also chose a similar motif, that of the mourning of László Hunyadi.

Cogniet devoted much of his life to teaching, spending 45 years as the art teacher at the Parisian Lycée Louis-le-Grand, and also teaching between 1847 and 1861 at the École Polytechnique; in 1851 he was appointed professor of painting at the École des BeauxArts, where he taught generations of painters until his retirement in 1863. His atelier privé was one of the most keenly sought, alongside those of Ingres, Delaroche, Gleyre and Picot. Among the reasons for his popularity was the fact that he never forced his own style upon his students, but always gave them the freedom to pursue their own path and to develop in their own way.

When Madarász first exhibited at the Salon de Paris in 1861 - having submitted, among others, his Mourning of László Hunyadi ${ }^{53}$-, he made sure that his name in the catalogue was accompanied by the fact that he had been a pupil of Léon Cogniet. As observed by Alain Bonnet, ${ }^{54}$ mentioning the name of one's teacher in the Salon catalogues was more than just a sign of respect or a kind of spiritual link. A well-known name - directly or indirectly - could open many doors and assist a young artist's career. At the Salon of 1861, the majority of prize-winners were students of Léon Cogniet, who was himself a member of the jury. It is possible, though it can never be proven, that a certain degree of favouritism was at play when the prizes were awarded. It is beyond doubt, however, that Cogniet's atelier was one of the most popular among young artists, who greatly appreciated his artistic approach.

The high esteem in which Cogniet held Madarász's talents is underlined by the recommendation he gave a few years later to a Hungarian count, Miksa Teleki, 


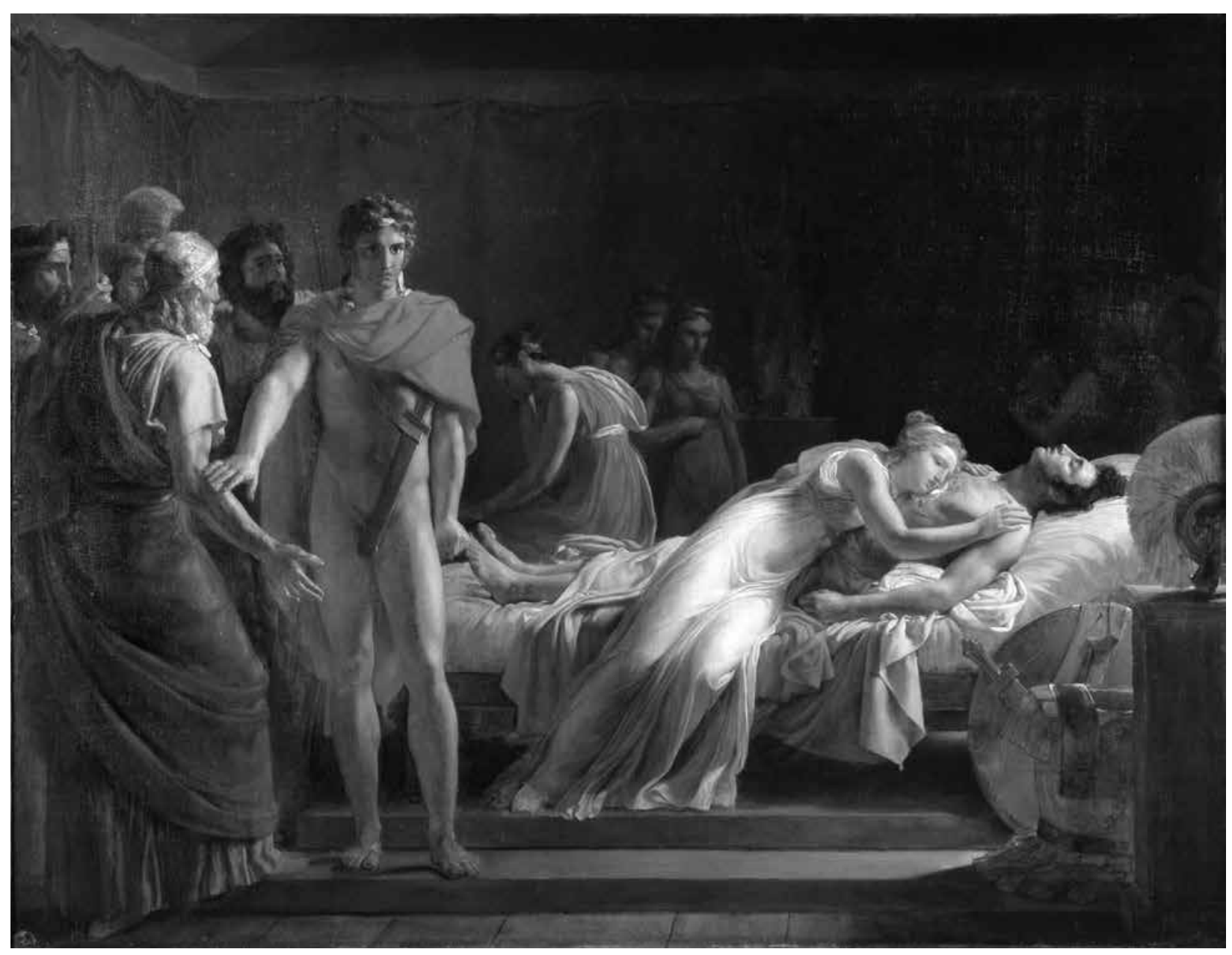

Fig. 7. Léon Cogniet: Briseis Mourning Patroclus, 1815;

oil on canvas, $113 \times 146$ cm; Orléans, Musée des Beaux-Arts, inv. no. 202 (@ François Lauginie)

who was looking for an artist to paint an episode from his family's past. "When Count Miksa Teleki wrote from Transylvania to my master, Cogniet, ordering from him a picture portraying Blanka Teleki in captivity in Kufstein, Cogniet immediately refused the Hungarian magnate's commission, recommending me, as a Hungarian, in his stead." 55 The countess Blanka Teleki had also been a student of Léon Cogniet in the second half of the $1850 s^{56}$ (around the same time as Madarász), hence the connection of the Hungarian noble family with the French master. In the abovecited memoir, Madarász goes on to report how Teleki, at first sceptical about Cogniet's recommendation, only became enthusiastic after seeing Zrinyi and Frangepán when it was exhibited in Pest (which Teleki immediately bought and gifted to the Hungarian National Museum), at which point he commissioned Madarász to execute the painting. ${ }^{57}$ Before sending it to Transylvania, Madarász exhibited the finished work at the Salon de Paris in 1867 (Fig. 8). ${ }^{58}$
Madarász's style was not only influenced by his academic training and his master, but also by the painting of Paul Delaroche..$^{59}$ In 1857, Madarász could have seen in person the works of Delaroche exhibited in the Palais des Beaux-Arts. Simply living in Paris had the capacity to improve and nourish the visual experiences of foreign artists, especially as contemporary painting was there waiting to be discovered, both at the Salons and at the Musée du Luxembourg, which was dedicated to the works of contemporary painters. The Musée de Luxembourg functioned as the "anteroom" to the Louvre, where paintings bought by the state at the Salon de Paris were initially shown; the paintings would be promoted from the "museum of living artists" to the Louvre after the artist died. The Musée du Luxembourg was a repository of the cream of contemporary French painting, at least in terms of art that was supported and "canonized" by the French state. Alongside the Louvre, it enabled young artists to train themselves by making copies of the paintings 


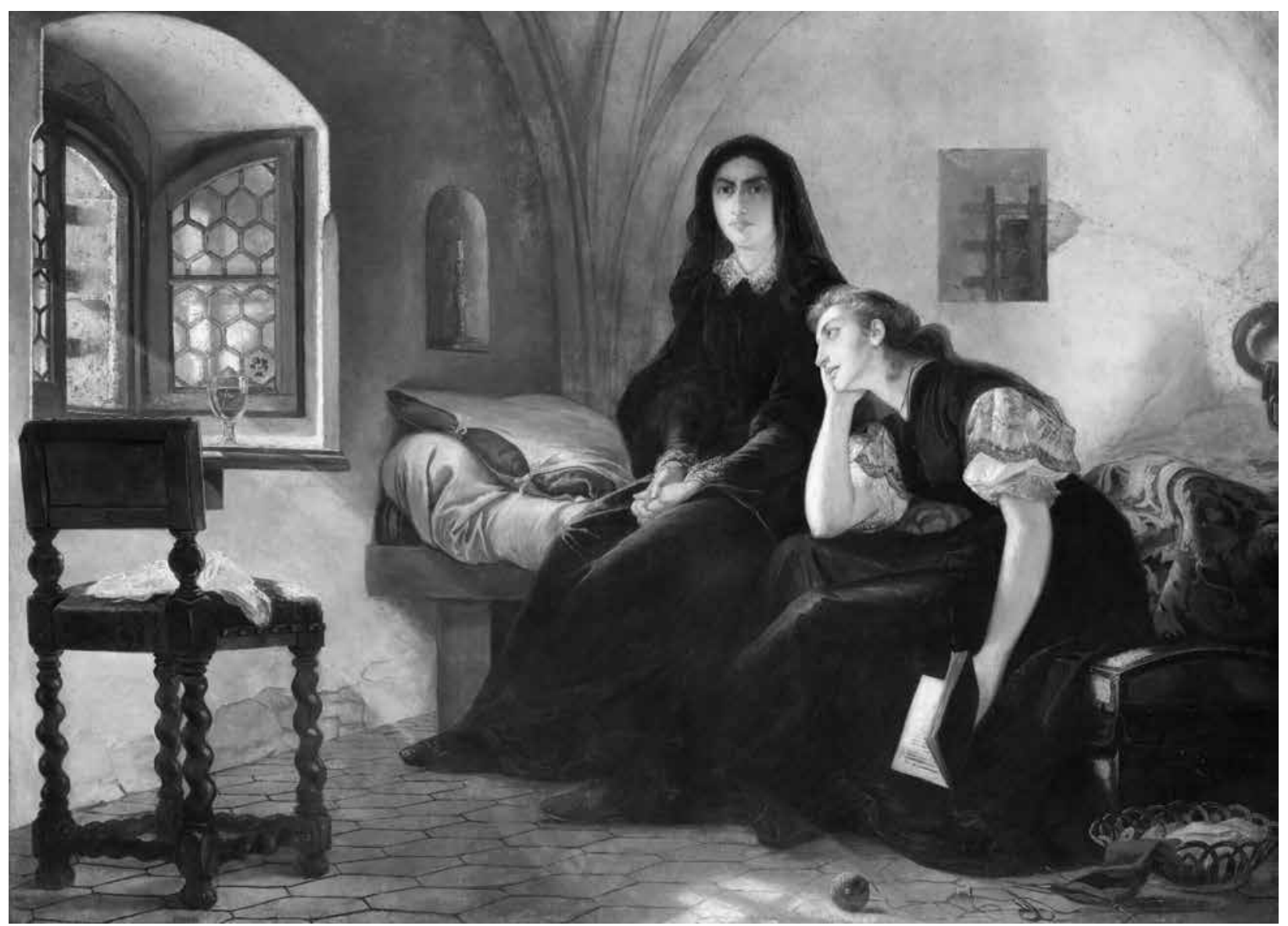

Fig. 8. Viktor Madarász: Countess Blanka Teleki and Klára Leövey in Prison at Kufstein, 1867; oil on canvas, $174 \times 241 \mathrm{~cm}$; Hungarian National Gallery, Budapest, inv. no. 71.62 T (@ Szépmúvészeti Múzeum - Magyar Nemzeti Galéria)

on display, a practice that became a fundamental part of art education in this era. The collection of the Hungarian National Gallery contains a small, unfinished sketch copy by Madarász ${ }^{60}$ of a painting by Eugène Delacroix, titled Jewish Wedding in Morocco (Fig. 9). ${ }^{61}$ Madarász would have seen Delacroix's original in the Musée du Luxembourg, ${ }^{62}$ where it was placed after the French state purchased the work from the artist at the Salon of $1840 .{ }^{63}$ In addition to visiting the museums during his sojourn in Paris, Madarász never missed a single Salon, where he also exhibited regularly between 1861 and 1869 .

The fourteen years that Madarász spent in Paris were responsible for his most important works, such as the Mourning of László Hunyadi (1859), Zrinyi and Frangepán in Wiener Neustadt Prison (1864), ${ }^{64}$ and Dobozi (1868; Fig. 10). ${ }^{65}$ The paintings he made at this time were mostly historical tableaus and portraits, the majority of which were related to Hungarian history. Madarász was always happy to present his works at the Salon, ${ }^{66}$ where they were generally well received by the critics, including the noted
French writer Théophile Gautier, who - as demonstrated below - formed a bond of friendship with the Hungarian painter. ${ }^{67}$ The Mourning of László Hunyadi (Fig. 11) stands out in the oeuvre of Viktor Madarász, and is to a certain extent separate from the rest of his paintings ${ }^{68}$ therefore deserves a more detailed analysis. The work, "with its strong and effective devices, its Victor-Hugoesque pathos and its painterly richness", executed amid the "atmosphere of French romanticism" - to quote the art critic Zoltán Farkas ${ }^{69}$ - is unquestionably an emblematic masterpiece not only in the artist's œuvre, but in nineteenth-century Hungarian history painting as a whole, marking a high point in what is known as Hungarian "national romanticism". ${ }^{70}$

\section{The Mourning of László Hunyadi ${ }^{71}$}

In the aftermath of the failed Revolution of 18481849, the demand for national history painting in Hungary gathered renewed momentum. Countless 


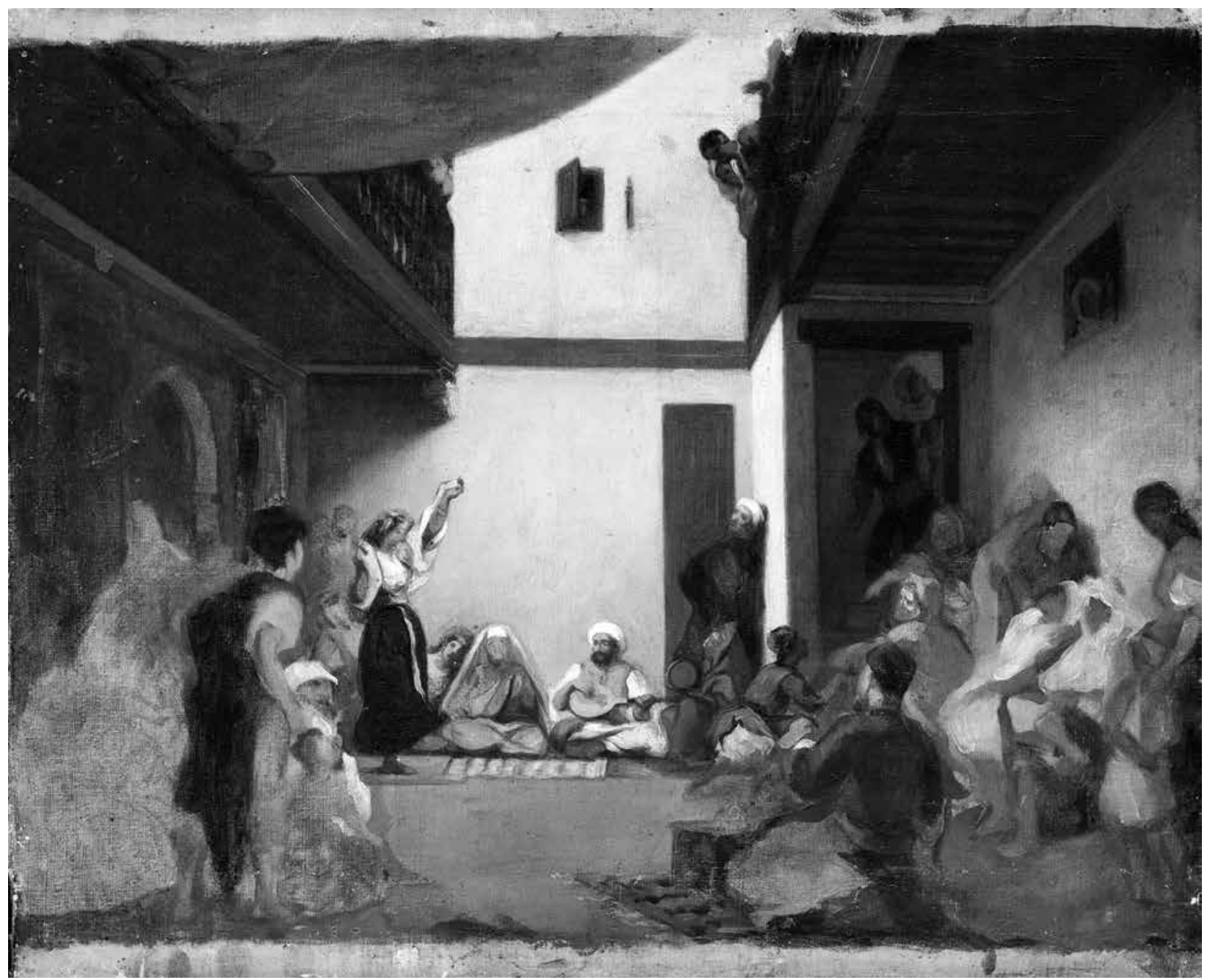

Fig. 9. Viktor Madarász after Eugène Delacroix: Jewish Wedding in Morocco, between 1856 and 1859; oil on canvas, $38 \times 46.2$ cm; Hungarian National Gallery, Budapest, inv. no. 4968 (C Szépmúvészeti Múzeum - Magyar Nemzeti Galéria)

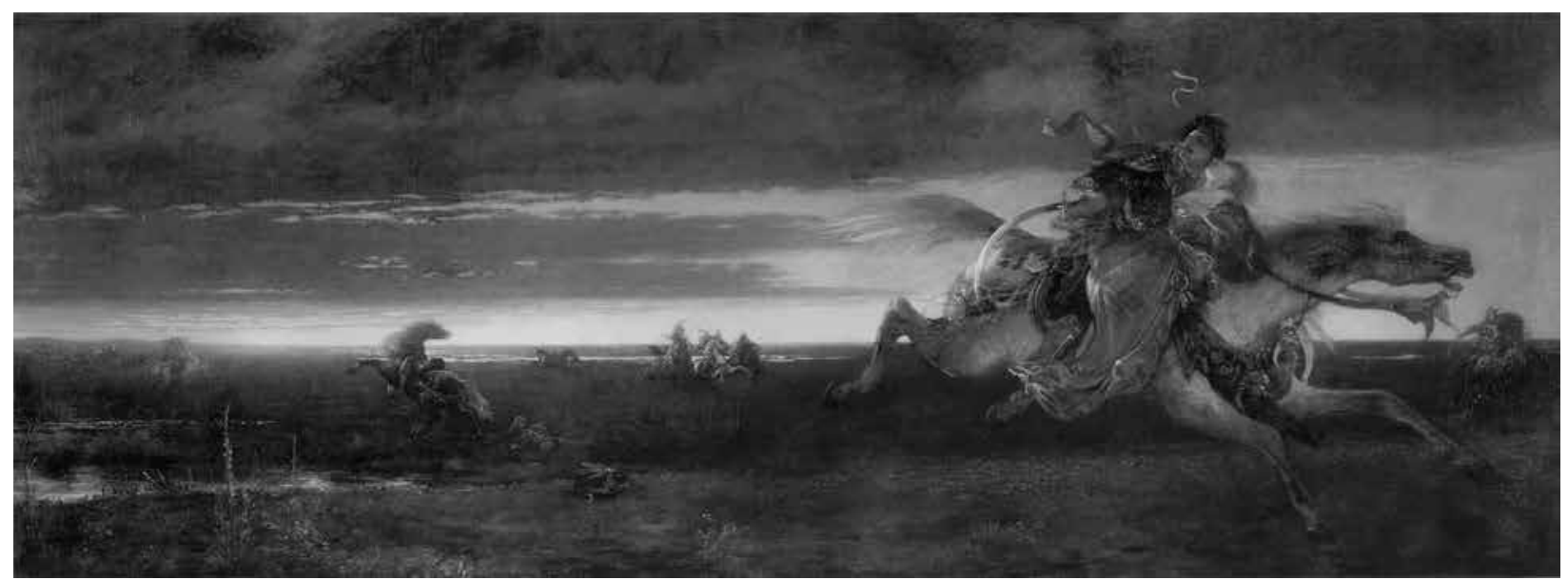

Fig. 10. Viktor Madarász: Mihály Dobozi and his Spouse, 1868; oil on canvas, $116 \times 311 \mathrm{~cm}$; Hungarian National Gallery, Budapest, inv. no. 59.153 T (@) Szépmúvészeti Múzeum - Magyar Nemzeti Galéria) 


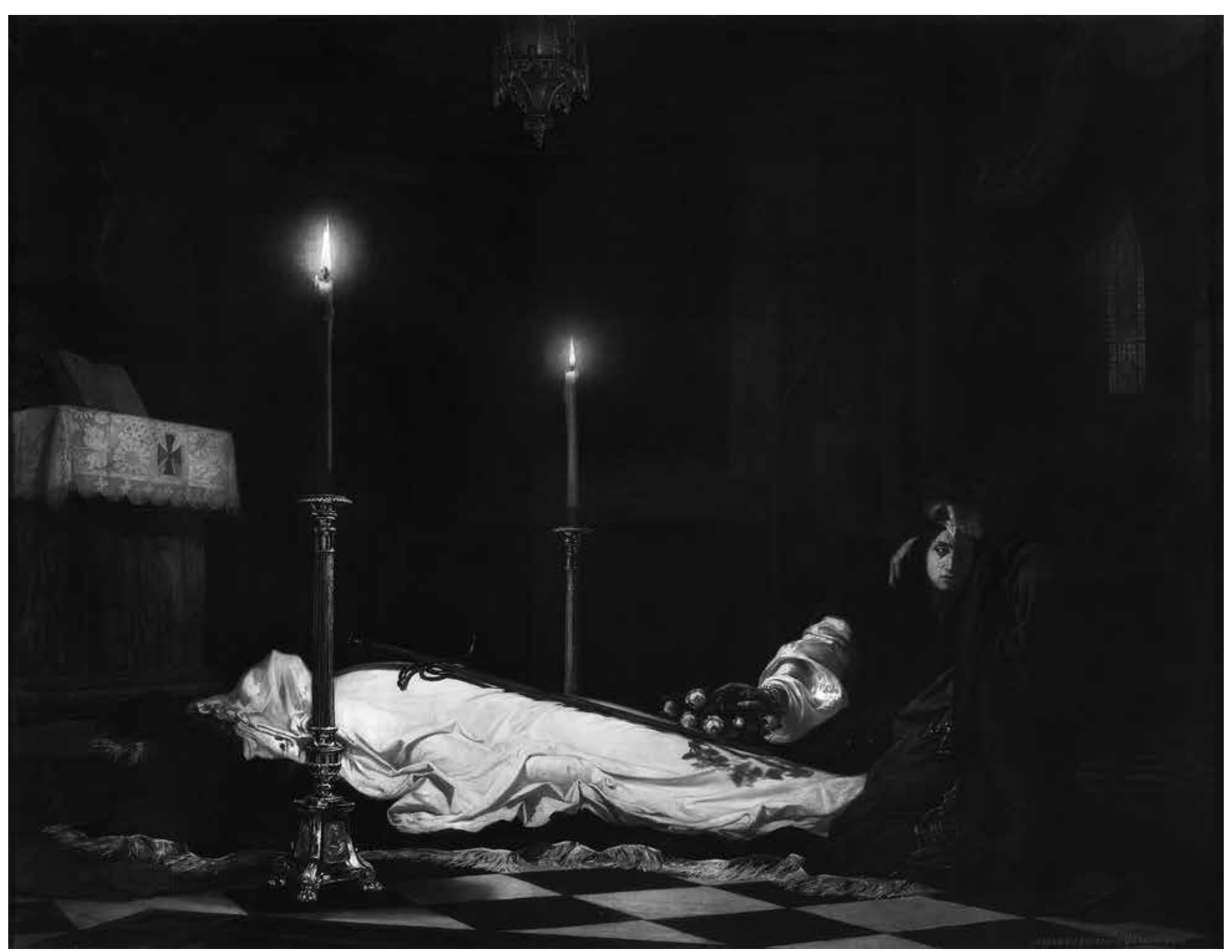

Fig. 11. Viktor Madarász: Mourning of László Hunyadi, 1859; oil on canvas, $243 \times 311.5$ cm; Hungarian National Gallery, Budapest, inv. no. 2800 (@ Szépmûvészeti Múzeum - Magyar Nemzeti Galéria)

monumental works effusing pathos and tragedy were created, memorialising decisive events of yore that had matured into symbols of the nation's history, immortalising scenes from what the specialist literature has defined as the "national history of suffering":

After the freedom fight, in the atmosphere of absolutism, history paintings with a new approach appear in public exhibitions, projecting before viewing audiences the different stages of a "national history of suffering". In 1850 Soma Orlay Petrich exhibits his large, sombre canvas, the Discovery of the Body of King Louis II, and in 1855 Viktor Madarász presents the work titled Kuruc and Labanc, which is followed in 1856 by the Dream of the Fugitive, and then in 1859 by the most influential painting of this type, the Mourning of László Hunyadi. We see a history that is nothing but tragic, with failing heroes and images of destruction. Although these works depict specific moments from history, their allegorical meaning is closely linked to the present, to the oppression that followed the failed revolution and to the lamentable experiences of national disunity. [...] These are not merely images of events, but "images of national destiny", whose substance reaches beyond the specific episodes they depict. [...] The actual objective of the painters was not simply to evoke the nation's martyrs, but through evoking them to urge the administration of historical justice, and to present the morally just side of history. ${ }^{72}$

In the painting, László (Ladislaus) Hunyadi (14311457), son of János (John) Hunyadi (the "TurkBeater") (ca. 1407-1456) and brother of the future King Matthias I (Matthias Corvinus) (1443-1490), lies before the altar of the Church of Mary Magdalene in Buda. Hunyadi was beheaded on 16 March 1457 upon the orders of King Ladislaus (László) V (1440-1457), who feared for his crown, thus breaking the oath he 


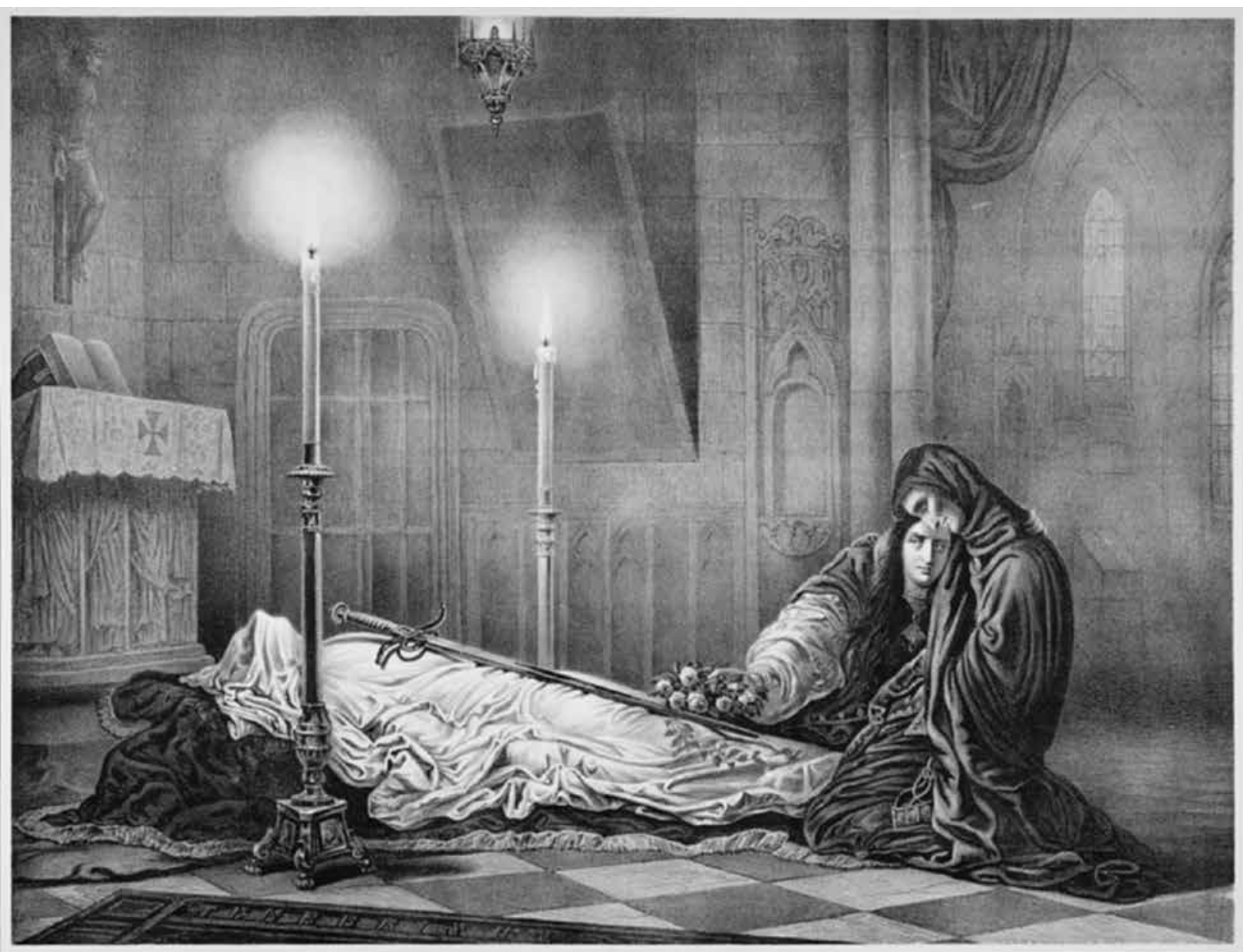

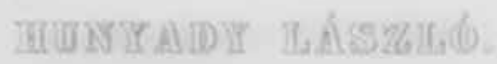

Fig. 12. Alajos Rohn after Viktor Madarász: Mourning of László Hunyadi, 1860; lithograph on paper, $475 \times 550$ mm, illustrated page of Képes Újság, first half of 1860; Hungarian National Museum, Hungarian Historical Gallery, Budapest, inv. no. 1625 (C Magyar Nemzeti Múzeum / Kardos Judit)

had sworn to protect the Hunyadi family. The story of László Hunyadi was extremely popular in nineteenthcentury Hungary, for it allowed writers to discuss the perfidy and immorality of a foreign ruler, and thus became the basis for numerous literary and theatrical works. ${ }^{73}$ By choosing this theme for his painting just a decade after the quelling of the Hungarian Revolution, Madarász was clearly demonstrating his republican, anti-Habsburg views. With the call to resistance implicit in its subject matter, this work, painted during a time of total oppression, made an important contribution to strengthening the "emotional foundations of national consciousness" ${ }^{\prime 4}$ in Hungary, especially as it was widely distributed throughout the land in the form of printed reproductions (Fig. 12). ${ }^{75}$
The fifteenth-century hero was thus transformed into a symbol of 1848, and Madarász's work became the emblematic painting of national self-sacrifice. The idea of self-sacrifice is reinforced by the composition of the painting, which follows the iconography of the Lamentation of Christ. Two women are kneeling before the catafalque: Hunyadi's mother, Erzsébet (Elizabeth) Szilágyi (1410 - ca. 1483), and his betrothed, Mária Gara, who is mostly known from works of literature and from the eighteenth- and nineteenth-century dramas about Hunyadi; the two women clearly recall the Virgin Mary and Mary Magdalene. Madarász created a true monument, which also bore witness to the "sanctification of national subject matter". ${ }^{76}$ This "Hungarian Pietà"77 represented "one of the stations 
along the nation's Way of the Cross". ${ }^{78}$ Following this painterly topos through to its conclusion, the painting also offered a promise that the Hungarian nation would rise again.

Madarász's role model, in several respects, was Paul Delaroche, the "Chorführer" of the new school of history painting, as he was described by Heinrich Heine at the 1831 Salon. ${ }^{79}$ Just like the French master, ${ }^{80}$ Madarász made a detailed study of the available historical accounts, including stage plays and other works of literature, which were at least in part based on historical evidence. It is true that the painter also added some fictive details to the original story, such as the presence at the catafalque of not only the victim's fiancée but also his (already deceased) mother; this provoked some negative comments from a few critics, although the two figures are essential to the composition and the dramaturgy of the work. Again like Delaroche, Madarász strove to "embed the historical event within the picture space, that is, he elaborates the spatial continuity around the event in order to capture the viewer's imagination". ${ }^{81}$ The elements of the painting that achieve this are: the two candles, almost the only source of illumination, which filter the light in the chapel and generate a sombre atmos- phere; the contour of the corpse that can be made out beneath the white sheet; and the almost imperceptible signs of the victim's terrible death: the red patch on the sheet at neck height ${ }^{82}$ and the bloodied sword placed beside his body. These details all prove that Madarász was aware of - and had indeed perfected - the types of components and structures typically found in the art of Delaroche, some subtle, some heightening the drama. ${ }^{83}$

The Mourning of László Hunyadi was a trailblazing master work of Hungarian national romanticism. Through countless reproductions, the painting has become firmly embedded in Hungary's collective visual memory over the last century and a half, to the extent that it now constitutes part of the national identity. Madarász himself made several different versions ${ }^{84}$ of the picture (both sketches and reductions ${ }^{85}$ ). The large-format version earned him a third-class medal at the 1861 Salon de Paris. ${ }^{86}$ This was the painter's first major award, and it brought him wide-ranging interest. Besides the caricaturist Galletti (Fig. 13), ${ }^{87}$ the French writer and critic Théophile Gautier also took note of the painting's originality. ${ }^{88}$ Madarász later became friends with the critic, ${ }^{89}$ who acquired one of the reductions of the painting. ${ }^{90}$

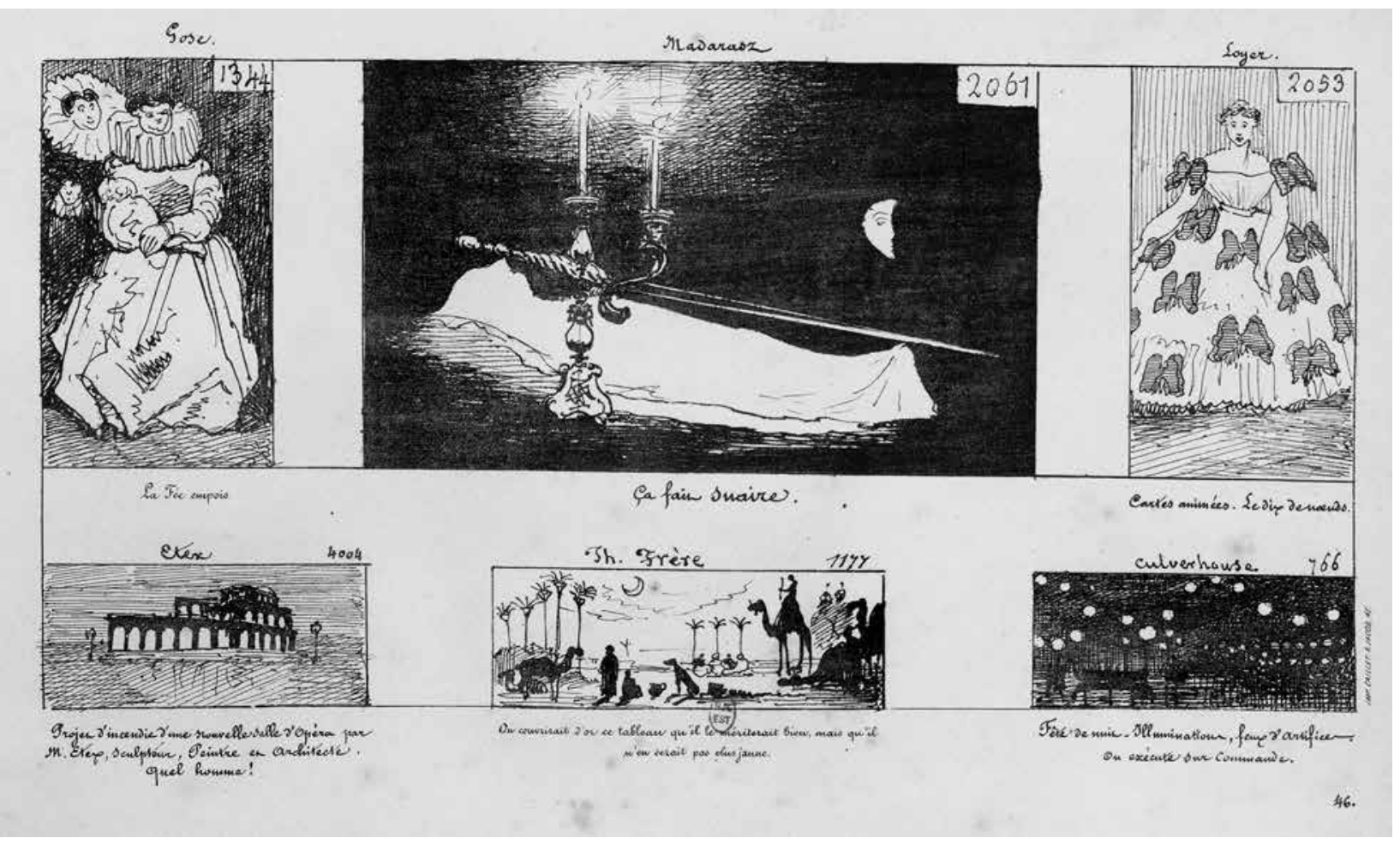

Fig. 13. L. Galletti: Caricature of the painting Mourning of László Hunyadi by Viktor Madarász (upper center), 1861. (Salon de 1861. Album caricatural par Galletti. Paris, Librairie Nouvelle, A. Bourdilliar \& Cie Editeur, [1861]; (C) Bibliothèque nationale de France) 


\section{Madarász and Théophile Gautier}

Besides talent, an important prerequisite for artistic success in the nineteenth century (as is still true today) was relationship capital. Artists devised different strategies in order to move forward in their careers, mostly based on conscious decisions, but not in every case. After all, the two states of alienation - drifting in isolation or melting into the crowd - both heralded the death of a career as an artist. Two conditions were therefore of crucial importance if an artist was to have a chance at success: artistic talent combined with originality, and contacts with the world of art and society.

How did it come about, however, that Théophile Gautier (Fig. 14), one of the period's most important French writers and critics, became acquainted - and later good friends - with the young Viktor Madarász? When and how did they first meet? How did they become friends? And what exactly did this relationship have on the painter's career? The writings on Madarász that have been published to date, as well as the Hungarian-language sources, answer none of these questions, even though the literature on the painter never fails to mention the friendship between the two men. Even the French author Antoinette Ehrard, who wrote a study specifically dealing with Gautier's contacts with Hungarian artists, made no mention of the origin and character of the relationship between Gautier and Madarász. ${ }^{91}$

It has been widely - yet, it transpires, wrongly reported that Gautier first took notice of Madarász and his Mourning of László Hunyadi at the Salon de Paris of 1861; in consequence, the story goes, the two men became acquaintances, and then friends, and this resulted in Madarász being welcomed into the Parisian art world with open arms. One of the first such accounts, related by Ödön Kacziány, was published while Madarász was still alive, in the art periodical Mũvészet, edited by Károly Lyka: "The painting of Mária Gara and Erzsébet Szilágyi at the catafalque of László Hunyadi was exhibited and awarded a medal. Gautier praised it in a warmly written article in Le Moniteur, bestowing absolute recognition on the artist's talent. A review by Gautier was a notable event in the art world. Following the example set by the polite French, the young artist, dressed in traditional Hungarian garb, visited the critic to thank him for his attention. He was given the most heartfelt welcome, and invited to attend the famous and momentous Thursday soirées, which were visited by the crème de la crème of the Parisian literary and artistic scene; later, for many years, he was among the most intimate friends of the Gautier family." 92 The writings on Madarász that have appeared in the last century including the latest monograph, published a few years ago - all perpetuate the same narrative, with more or less the same level of detail. ${ }^{93}$ The true story, however, is more prosaic than this.

While it is true that Madarász came to know the elite of the Parisian art world under the aegis of Gautier, their first meeting took place under quite different circumstances, as related in a first-hand account from France. ${ }^{94}$ In the memoir of Théophile Gautier's daughter, Judith Gautier (Fig. 15), who also made a living as a writer, she provides a detailed and enjoyable recollection of the social events that took place in the Gautier household, and of Gautier's artist contacts. Her memoir is an important source of information on the (social) history of Parisian art and culture in the second half of the nineteenth century; like all similar subjective and retrospectively written works, however, it must be read with a critical eye. Nevertheless, the authenticity of the information it contains is warranted by the so-called "autobiographical pact", an institutionalised "contract" whereby the author of such a work - as both narrator and protagonist - undertakes to tell what happened in adherence with the facts. ${ }^{95}$ Although the memory of the events may have been impaired by the time that passed since they took place, they can still be regarded as reliable sources, in that they are honest attempts to record the truth.

Like most of his fellow artists, the young Madarász undoubtedly did all he could to get his foot inside the door of the Parisian art scene. He would have understood the importance of the Salon, and of how success there could mark a turning point in the fortunes of an artist. When the Salon jury - which included, it is fair to add, Madarász's master, Léon Cogniet approved three of his paintings for exhibition, he was emboldened to take yet another step in the interests of furthering his progress. In Judith Gautier's memoir we can read ${ }^{96}$ that Madarász himself went and asked Gautier for his support, even before the critic had paid any attention to his paintings at the Salon of 1861. Madarász was certainly aware that "the articles of the great critic, more than all others, could make a reputation". ${ }^{97}$ The art criticism Gautier wrote from 1836 until his death established him as an authority in the art world and one of its defining voices. The reviews he wrote about the annual exhibitions at the Salon were published in Le Moniteur Universel, the official journal of the Second Empire. He was friends with 


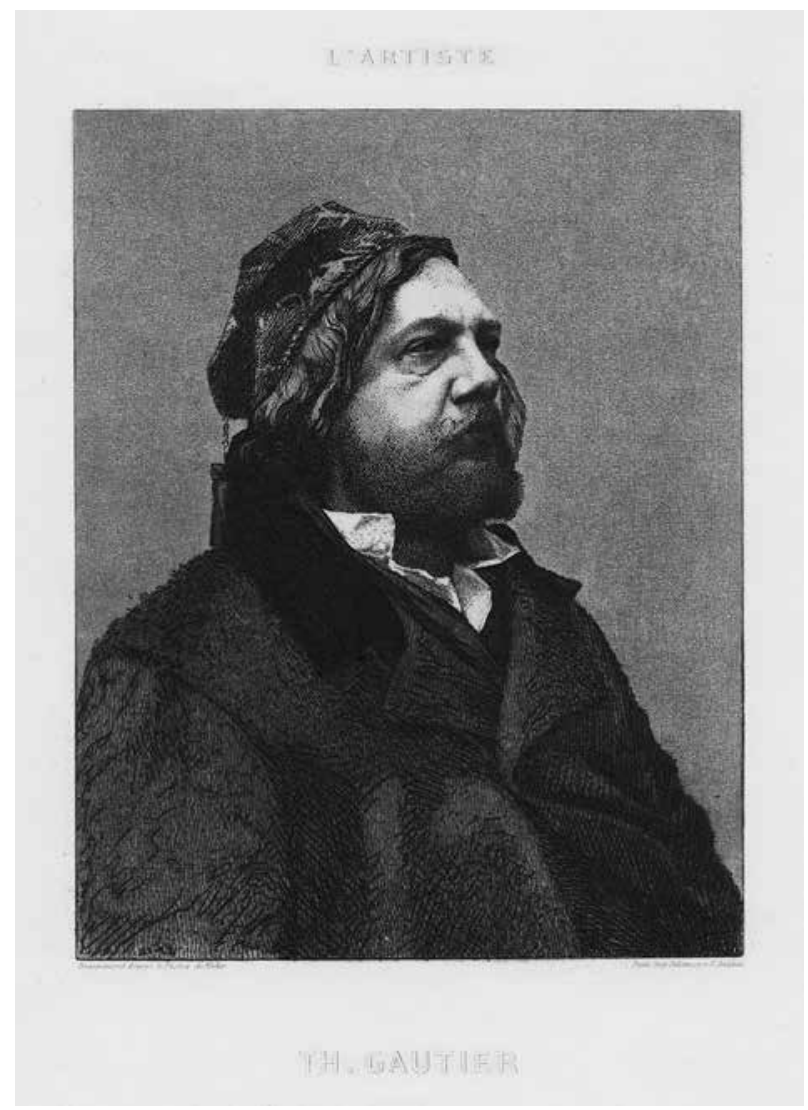

Fig. 14. Théophile Gautier, engraving by F. Bracquemond, 1859, after a photograph by Nadar

(@) Conseil départemental des Hauts-de-Seine / V. Lefebvre)

countless French artists and writers (Flaubert, Baudelaire, Delacroix, Ingres, Doré, to mention just a few), and according to his surviving correspondence, ${ }^{98}$ he never hesitated to rush to the aid of his friends or to do them favours. His artist friends were always grateful for his support and for the articles he wrote in praise of their work. ${ }^{99}$ Judging from his written legacy, it seems that among foreign artists, Gautier took an especial interest in the works of Hungarians. ${ }^{100}$ He was not only close friends with Madarász, for example, but also with Mihály Zichy. Sometimes these threads of friendship would weave together. According to István Csapláros, "during their visit to Paris in 1862, the two Zichy brothers met Madarász in the company of Gautier." ${ }^{01}$ By this time, Madarász had been a regular guest at Gautier's home for a year. As told by Judith Gautier, the first meeting between the two men took place as follows:

One day in May, Gautier was sitting in his garden with his two daughters, Judith and Estelle, when a servant appeared, carrying a calling card, and announced a foreign gentleman with a peculiar name and appearance - a handlebar moustache and Hun-

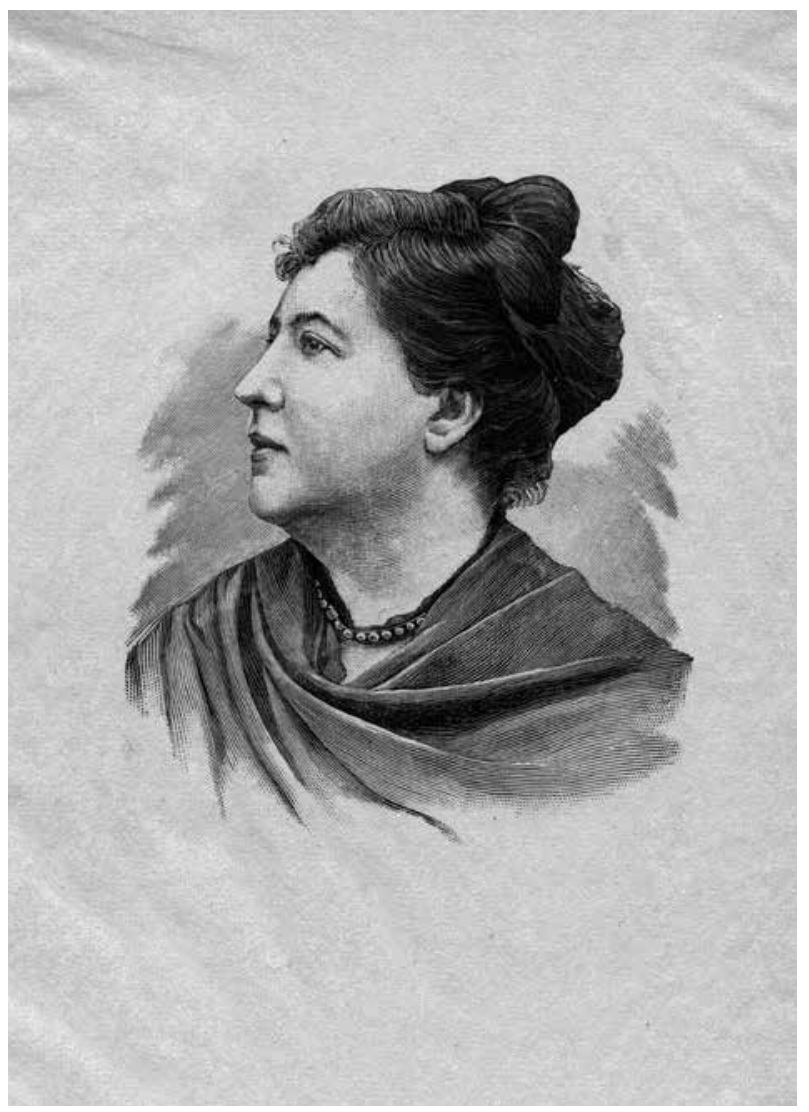

Fig. 15. Judith Gautier, heliogravure after a photograph, unknown creator, around 1900

(ㄷ Conseil départemental des Hauts-de-Seine / V. Lefebvre)

garian attire. Madarász appeared before the French eminence without forewarning and without a letter of introduction. "I beg your forgiveness, sir, for daring to present myself to you as a stranger and without any recommendation, but obtaining your protection is, for me, a matter of life or death, and it is your esteem itself that has lent me the courage to come to you and the confidence that you would receive me." 102 Gautier, at this time, still had no idea who the painter was, but he was not taken aback; after all - as demonstrated by his copious correspondence - artists (painters and poets), both famous and unknown, turned to him for help on an almost daily basis. Gautier first asked him if he had a source of income, for if not, it would perhaps be more prudent to pursue a different career; he then told him that talent was not by itself a guarantee of success, not by any means. Judith Gautier spends several pages describing the conversation that ensued. Madarász proudly announced that three of his paintings had been accepted for exhibition by the Salon de Paris, and he spoke about their subject matter. Gautier was initially unimpressed by the grim and gloomy themes. However, as he considered the artist himself 


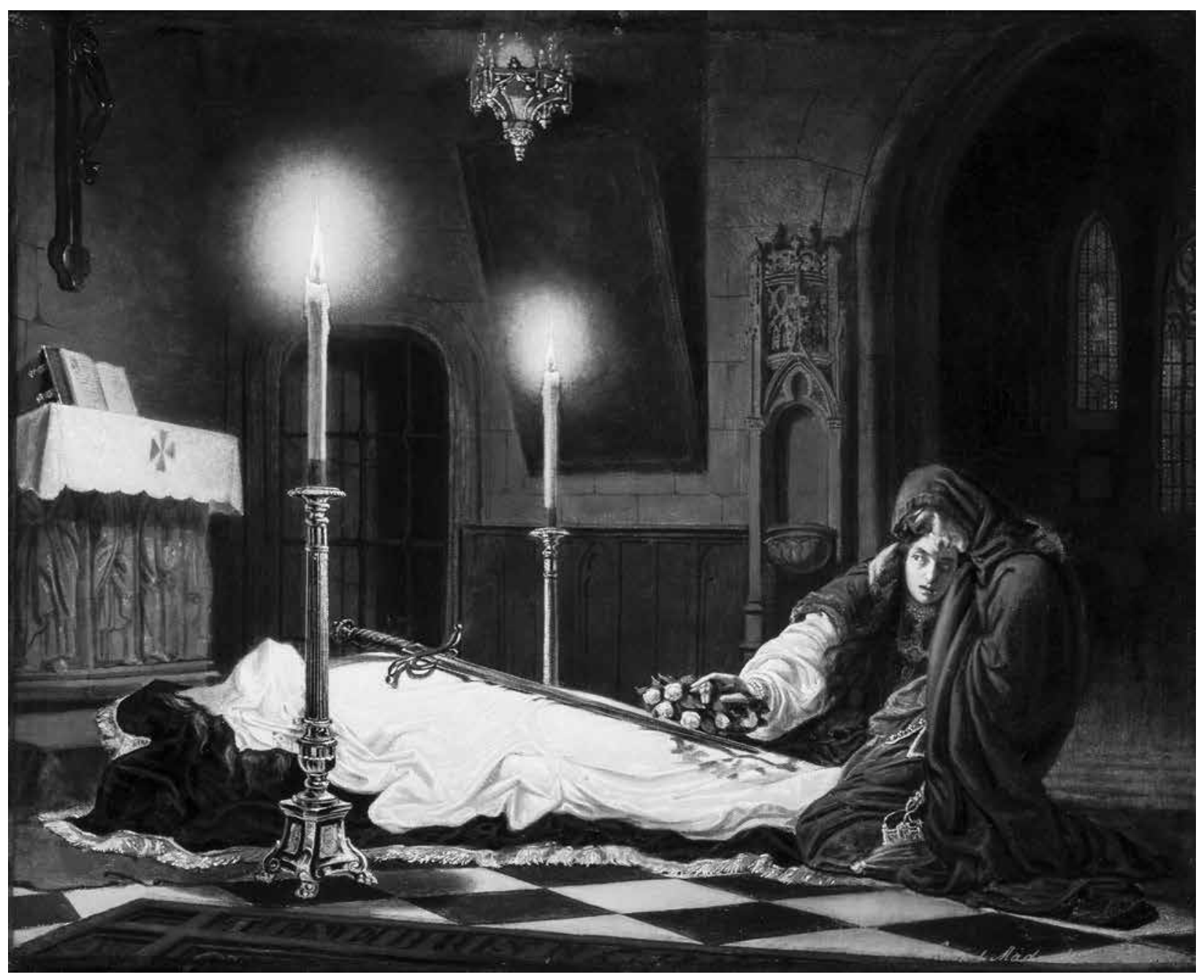

Fig. 16. Viktor Madarász: Mourning of László Hunyadi (Reduction), 1860; oil on canvas, $46 \times 57 \mathrm{~cm}$; previously owned by Theophile Gautier, private collection

to be quite affable, he promised to take a look at the works and to write about them for the public to read. Gautier found the Hungarian artist so likeable that he prolonged the conversation to impart some words of counsel: "Above all, pay no attention to the advice of M. Prudhomme ${ }^{103}$ to renounce your originality in order to be just like everybody else! Your boots and your soutaches will bring you more attention than all the talent you may have." 104 Madarász accepted Gautier's wise words, and he gained a reputation - as Mihály Munkácsy would a decade later - for parading through the streets of Paris dressed in Hungarian national costume. It was probably not by chance that he wore the same clothing in the youthful self-portrait he presented to the Parisian public at the next Salon de Paris, in 1863 (Fig. 1).

Judith Gautier finally reports that Madarász was extremely grateful for the reviews her father wrote about him, and that he visited them often, soon becoming good friends with the whole family. In a letter Judith wrote in 1866 to her future husband, Catulle Mendès, she wrote of the painter, "He is a man of utter loyalty, this Madarász, proud, determined and unfortunate; a grand lord in his homeland, he starves to death in Paris due to his love of Art and his stubbornness." 105 The artist's name turns up several times in later chapters of the memoir, as a regular participant at the Thursday soirées and as a guest at the "risotto evenings", where he would play charades just as eagerly as he would join in with the cooking. ${ }^{106}$ Madarász even painted a picture of Myrza, the Havanese dog belonging to Gautier's wife ${ }^{107}$ - the fate and whereabouts of this animal portrait are currently unknown. Madarász thus became a member of what Judith Gautier called "these gatherings of illustrious and as yet unsung artists, who constituted a veritable court around my father during this era of the Salon". ${ }^{108}$ In addition to Madarász, among the other 


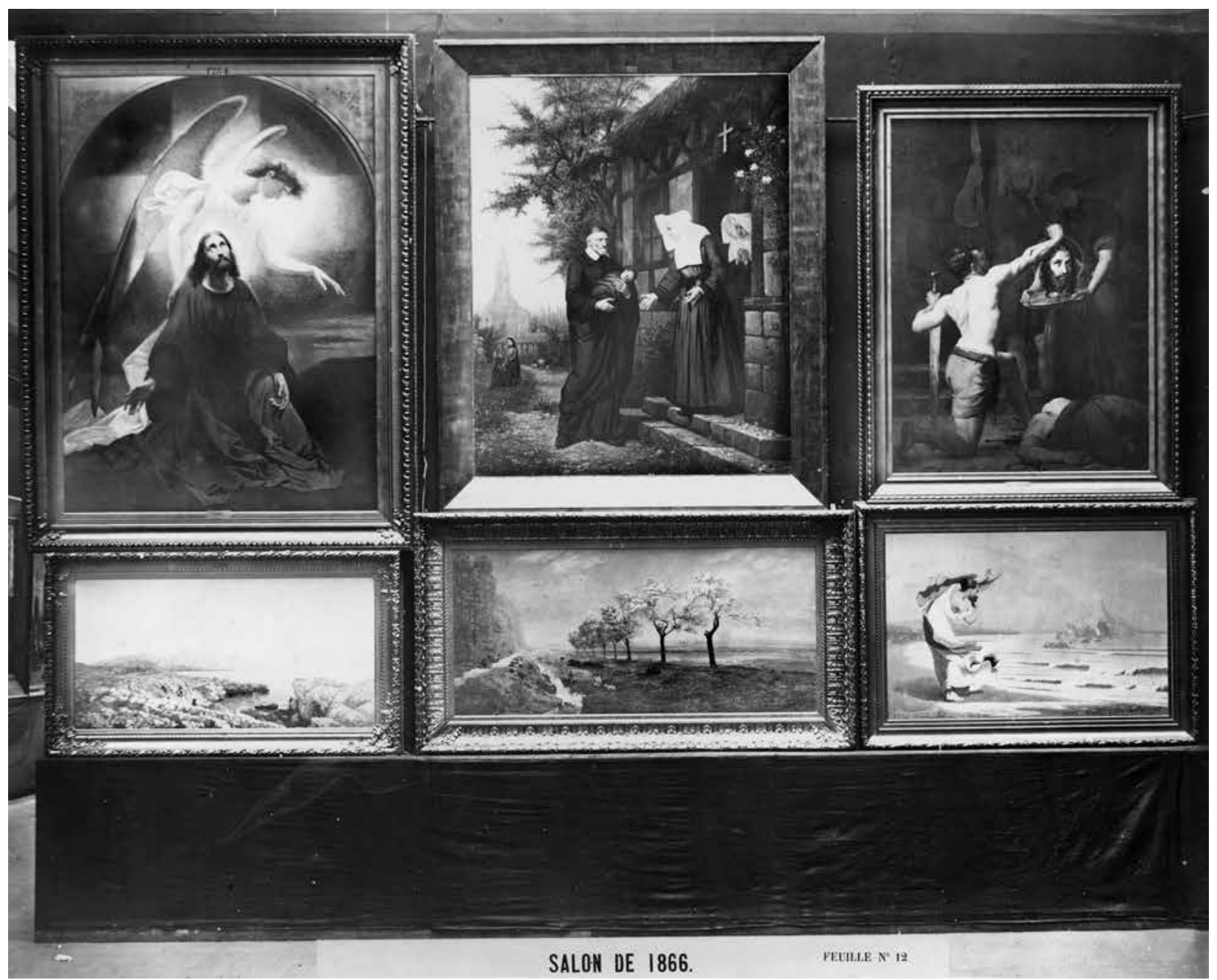

Fig. 17. Upper left: Viktor Madarász: Christ on the Mount of Olives, ca. 1866; Gironde, Saint-Caprais church (Reproduced in the album of the works acquired by the Ministry of the House of the Emperor at the Salon and photographed by Charles Michelez, Base Archim, inv. no. F/21/7637; @ Archives nationales, France)

regular guests at the Gautier home were the Goncourt brothers, Alexandre Dumas the Younger, the virtuoso pianist Élie-Miriam Delaborde, and the painters Ernest Hébert, Paul Baudry, Pierre Puvis de Chavannes and Gustave Doré - the latter was the main source of entertainment at the Thursday soirées. ${ }^{109}$ These anecdotal minutiae have been included here to illustrate the character of the friendship shared by Madarász and Gautier. Even if some parts of the memoir were "tinged by time", the basic facts cannot be disputed: it was not of his own accord that Gautier noticed and wrote a review of Madarász's paintings at the Salon (although we cannot rule out the likelihood that he would have done so anyway); and Madarász did not pay him a call in order to thank him in person. Indeed, rather the opposite was true: Madarász was the one who drew Gautier's attention to his paintings (and to himself), and it was his prepossessing nature that prompted Gautier's promise to look at the works and mention them in his column. The sentiments in his review, however, in all its length and praise, undoubtedly reflected his sincere opinion about Madarász's art.

It is irrefutable that the favourable reviews Madarász received, including those by Gautier, were instrumental in accelerating the painter's recognition and his career. Madarász seems to have expressed his gratitude to Gautier in more than words. It is highly likely that the artist gave the critic a small reduction of the Mourning of László Hunyadi (Fig. 16). The catalogue accompanying the auction of Gautier's estate informs us that, at the time of his death, he possessed a smallsized version of this painting. ${ }^{110}$ Gautier's correspondence and his surviving papers reveal that, after he published a positive article about them, painters and collectors would often make him gifts in expression of their appreciation. ${ }^{111}$ Among the works he obtained 
in this way was a watercolour by Mihály Zichy, dedicated personally to Gautier, ${ }^{112}$ which was probably the painter's way of showing his indebtedness to the critic for mediating during an exhibition of his works held in Paris in 1859 (Zichy sent his drawings to Gautier, who passed them on to the gallery) and for writing so positively about them - Gautier went so far as to compare Zichy with Delacroix. ${ }^{113}$ As a result of such donations, Gautier amassed a substantial art collection of his own, comprising several hundred items - among them pictures by Delacroix, Ingres, Baudry, Chassériau, Gérôme, Puvis de Chavannes, and Théodore Rousseau -, which he treasured immensely. ${ }^{114}$ The paintings adorning the walls of his home would have been seen regularly by his guests, and this was another way in which Gautier contributed to raising awareness of certain artists - including Zichy and Madarász among members of the Parisian art world.

Gautier may also provide the key to the mystery surrounding another work by Madarász, the painting entitled Christ on the Mount of Olives, which was bought from the artist by the French state at the Salon of 1866 (Fig. 17). This was a curious situation for two reasons: firstly, the Second Empire rarely purchased works by foreign artists, and apart from this single exception, the only other Hungarian painters to enjoy such a privilege were those who had acquired French citizenship (Charles Herbsthoffer and Adolphe Weisz). ${ }^{115}$ Secondly, Madarász hardly ever painted biblical themes. His paintings tended to deal with episodes from the tragically sombre history of Hungary, which rendered them thematically unsuitable for purchase by the French state, so the only way Madarász could scrape a living in Paris was by fulfilling portrait commissions. In the case of Christ on the Mount of Olives, the question arises of why the artist chose to undertake a painting in this genre, an area for which he seems to have had little natural affinity. In the absence of written sources, we can only guess that Madarász produced it in the hope of a state commission. We can also only surmise that Gautier - who mentioned the painting in his review of the Salon - intervened between the artist and those responsible for deciding which artworks would enrich the national collection of the Second Empire. The critic, who became a member of the Salon jury from 1864 onwards, often received requests for support and mediation from artists about whom he had written approvingly. Gautier was, of course, on good terms with the Count de Nieuwerkerke, the superintendent responsible for purchases of artworks for the Imperial House and for organising the annual Salon, whom he addressed as "my dear friend" in their correspondence. ${ }^{116}$ An artist named Emmanuel Lansyer (1835-1893), for example, expressly asked Gautier to persuade the count to have the state purchase one of his paintings. ${ }^{117}$ On another occasion, Gautier interceded to ensure that a painter named Jablonski earned an official state commission. ${ }^{118}$ These sources illuminate the political influence that Gautier wielded, which he may also have used in support of Madarász. Gautier may also have recommended Madarász to the cousin of Emperor Napoleon III, Princess Mathilde, the lover of the Count de Nieuwerkerke; Gautier worked as her librarian and, judging by the warm tone of their correspondence, they must also have been close friends. It is conceivable that the princess and Madarász might have met at Gautier's home, and that the state commission might have been arranged semi-officially in the garden of the writer's house in Neuilly.

Gautier's role as a mediator in Madarász's affairs is also evident from a newspaper account written by the artist in his old age: in order to facilitate Madarász's research into the eighteenth-century Hungarian Prince Francis Rákóczi, Gautier asked for help directly from Princess Mathilde, who gladly signed a "decree" allowing the painter entry into the Bibliothèque Nationale. ${ }^{119}$ Thanks to this intervention, Madarász could read, at first hand, the prince's manuscript autobiography, which served as the source of a later painting, entitled Rákóczi in the Prison of Wiener Neustadt (1905).

\section{Madarász at the Salon de Paris and his critical reception}

Now that Gautier's significance in the career path of Madarász has become more evident, let us turn back to his presence at the annual Salon where other critics had also shaped his artistic recognition. At his first Salon appearance in 1861, Madarász exhibited three paintings on historical themes: the Mourning of László Hunyadi (Fig. 11), Felicián Zách (Fig. 18) 120 and Ilona Zrinyi in Munkács Castle (Fig. 19). ${ }^{121}$ Two years earlier, Felicián Zách and the Mourning of László Hunyadi had already been on show at the exhibition of the Pest Art Society, prompting the great novelist Mór Jókai (writing under a pseudonym) to enthuse about the young artist in the columns of a Sunday newspaper. ${ }^{122}$ He declared Madarász a mastermind, who was "at the same time a poet as well as a sensitive soul". ${ }^{123}$ The critic of the newspaper Napkelet also celebrated the "creative mastermind" in him. ${ }^{124}$ The Hungarian 


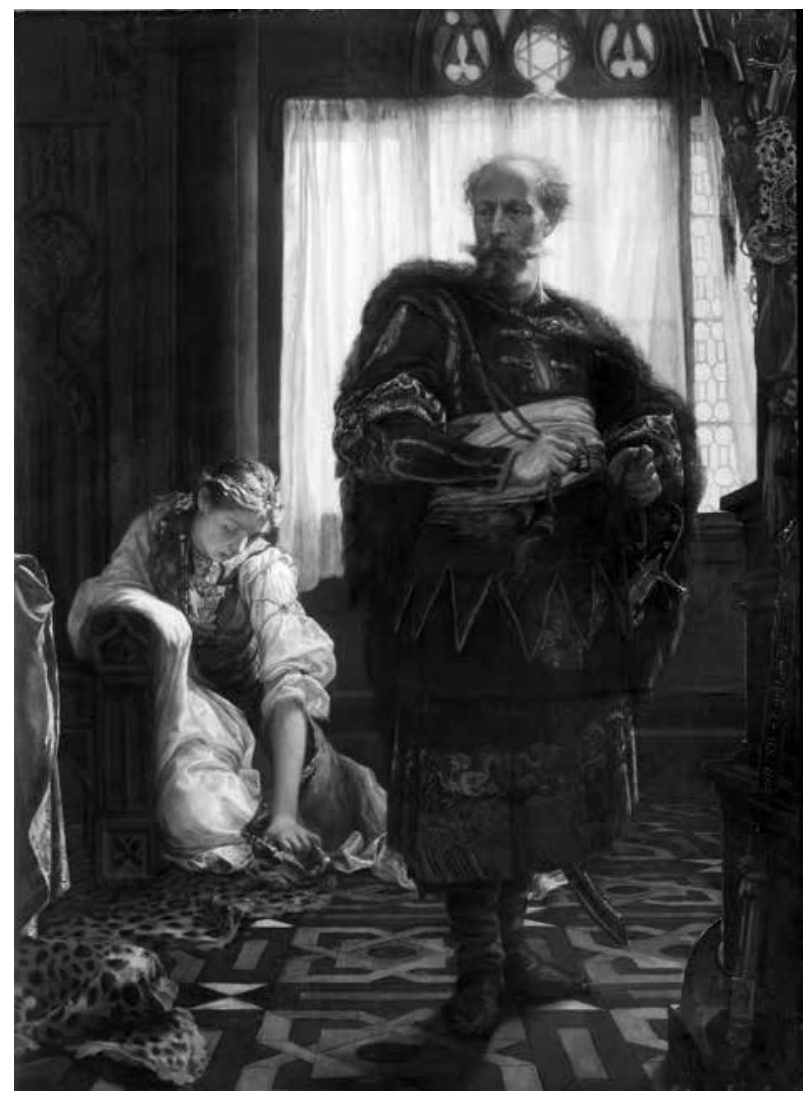

Fig. 18. Viktor Madarász: Felicián Zách, 1858; oil on canvas, $152 \times 111 \mathrm{~cm}$; Hungarian National Gallery, Budapest, inv. no. 66.14 T (@ Szépmúvészeti Múzeum Magyar Nemzeti Galéria)

painter was successful in Paris as well, but the opinion of the French critics was not so uniform. The critic for L'Artiste, for instance, was not so unconditionally enraptured: "Viktor Madarász is extraordinarily dramatic in presenting us with the dramatic history of his country. We say dramatic, whereas we should also like to say artistic. But this is the very thing which, at least at present, is lacking from Madarász: he is more of a poet than an artist. We would like to see both. Perhaps we expect too much, yet neither the one nor the other is too much. We are horrified by the bloody winding sheet that covers László Hunyadi, we can almost see the terrible collar that the henchman has left around his neck, and together we kneel down with the two women mourning him in the chapel - but when the initial impact has passed, we are left looking for something, a je ne sais quoi, which is absent from the picture. Yet in art, in the majority of cases, everything depends on this je ne sais quoi." 125

It is interesting that Madarász was referred to as a poet both in Hungary and in France. Other expressions related to "poetry" also crop up in connection with the painter. Gautier, for instance, wrote that "the composition of the picture is held together by a romantically sombre poesy". ${ }^{126}$ Gautier wrote at length about the painting, concluding that "Viktor Madarász is an original artist, who captures the viewer's attention at once, which is not easy among the countless characterless pictures that inundate the Salon". 127

Of the three paintings, there is no question today that the Mourning of László Hunyadi is the most important work. Immediately after the Salon, however, much was written also about Felicián Zách (Fig. 18):128 Léon Lagrange, for example, does not even mention the other two works, for in his view "of the three paintings, the most successful $[\ldots$ is the one...] in which the painter, with great dramatic sense and magisterial use of backlighting, depicts Felicián Zách, who is just learning that his daughter has been raped by Casimir". ${ }^{129}$ The word "dramatic" had already been used in the review in L'Artiste. Lagrange finally points out the "strange taste" that characterises the work of the Hungarian painter. Maxime du Camp, a friend of Gautier's (and godfather of his daughter, Judith), praises Madarász's handling of colour and the expressive power of all three paintings, before moving on to the virtues of Felicián Zách: "His three paintings, the László Hunyadi, the Felicián Zách and the Ilona Zrínyi, have very fine colour qualities. One can sense at first sight that this is a pupil of Léon Cogniet, and that the student has at least learnt to paint in the atelier of his master. The colouring is extremely strict but it has a certain harmony, for despite its vivacity, it never rings garishly out of tune. The Felicián Zách is almost a tour de force, for the main figure stands out in the dark against backlighting, yet maintains his bright colours, which seem perfectly natural."130

Although Madarász's paintings caught the attention of people in France because of their painterly qualities, the radical message contained within the works - often elevated to a symbolic level, and reflecting on topical Hungarian history - was not understood by the French public or critics. This is not surprising, for the hidden allusions would only have been apparent to those who knew the country's history well and were aware of the current political situation. Hungarian audiences fully comprehended that the painting of Felicián Zách was much more than a dramatic reenactment of a scene from the Middle Ages. Ten years after the bloody put-down of the Revolution, painting a picture of an historical figure who had attempted to assassinate a king who was deemed to be unjust and cruel was an act of patriotism. Furthermore, the axe 


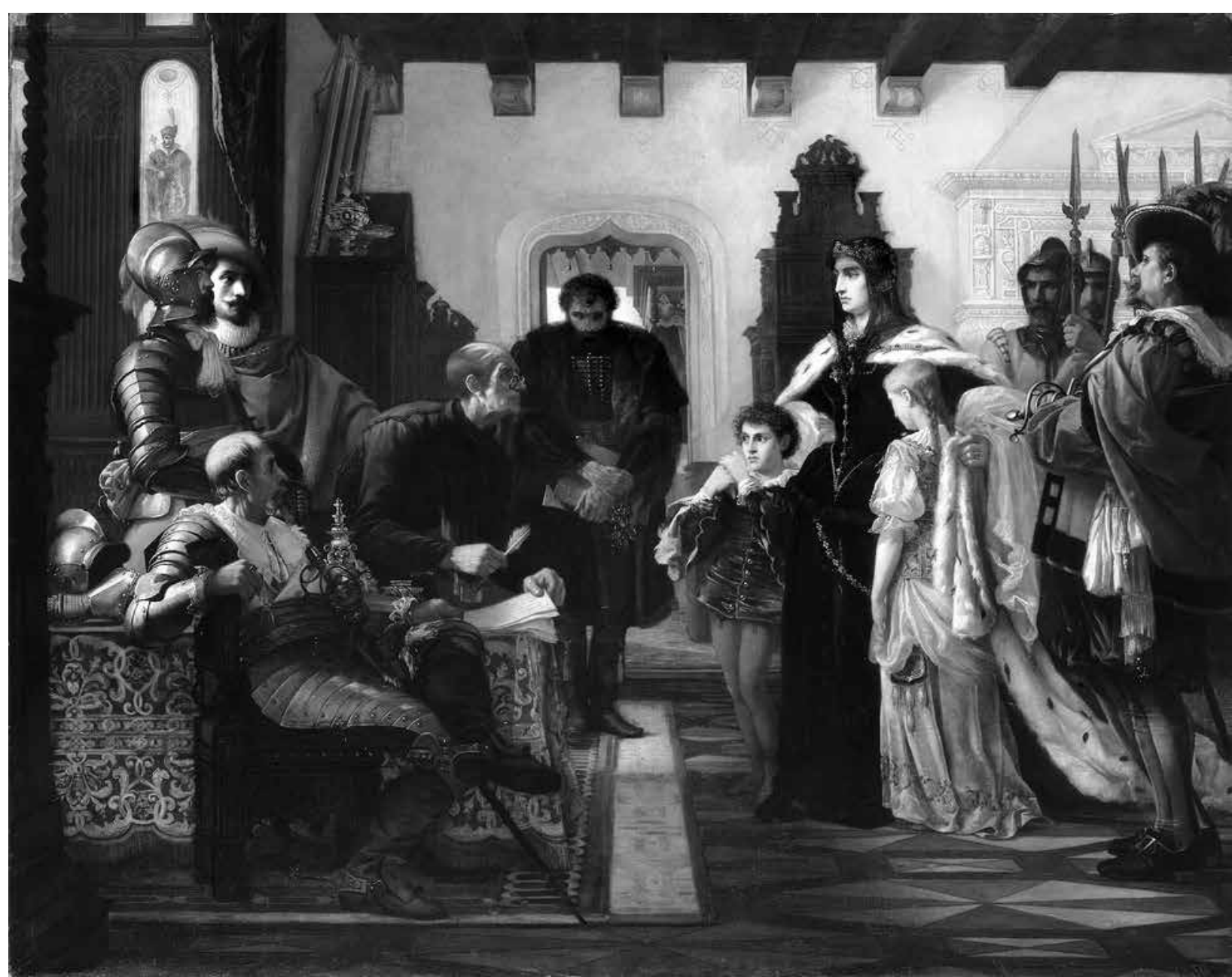

Fig. 19. Viktor Madarász: Ilona Zrinyi in Munkács Castle, 1859; oil on canvas, $146 \times 185$ cm; Hungarian National Gallery, Budapest, inv. no. 2805 (@ Szépmúvészeti Múzeum - Magyar Nemzeti Galéria)

resting on the ground beside the father's feet has multiple meanings: it is an omen of revenge, of course, but it also enables the artist to broaden the context. The inscription on the axe reads: NE BÁNTSD A MAGYART! ["Do not harm the Hungarians!"] It is wellknown to Hungarians that this phrase derives from the seventeenth-century statesman and poet Miklós Zrínyi, and was used as the title for later editions of a work originally titled Remedy against Turkish Opium. "With this inscription, the temporal horizon and associative content of Madarász's painting is significantly extended, so Felicián Zách is portrayed before us not only as an assailant of the king, but also as a symbolic personage who will avenge the sins committed against Hungary." 131

This type of concealed patriotic message is typical of all of Madarász's history paintings. The third work at the 1861 Salon depicted Ilona Zrínyi in Munkács Castle (Fig. 19). Ilona Zrínyi is one of the greatest female heroes in Hungarian history. She came from a patriotic, noble Croatian-Hungarian family, generations of whom had fought against Hungary's enemies (first the Ottoman Turks and later the Habsburgs), so Ilona was predestined to follow in the footsteps of her forebears. Miklós Zrínyi, her great-grandfather, had been one of the emblematic heroes of the struggle against the Turks. Her father, Péter Zrínyi, had opposed the Habsburgs' policies and had taken part in a conspiracy (1664-1671) led by Ferenc Wesselényi, resulting in his imprisonment and his eventual execution. (The episode inspired Madarász to paint Zrínyi and Frangepán in Bécsújhely Prison, which he exhibited at the Salon de Paris in 1864.) Ilona's second husband, Imre Thököly, was a commander in the anti-Habsburg rebellions of the 1680s, while her son, Ferenc Rákóczi II, led the most serious revolt against the Habsburgs in the early eighteenth century. After the death of her first husband, Ferenc Rákóczi I (1645-1676), Ilona 
Zrínyi, as the wife of Imre Thököly, played an important role in the uprisings of the Kuruc forces against the ruling Habsburgs.

In the mid-1680s, the Austrian imperial army marched from castle to castle, seizing every fortress held by the Rákóczi family. The last was Munkács Castle, where a siege began at the end of 1685, after Thököly had been captured. Ilona Zrínyi herself took up command of the defensive forces, and for two years she thwarted the siege, eventually succumbing at the beginning of 1688. In peace negotiations, she succeeded in obtaining an amnesty from the emperor for those involved in defending the castle, and she was granted permission to keep the assets of the Rákóczi family on behalf of her children. When they reached Vienna, however, she was separated from her children; she never saw again her son, Ferenc Rákóczi II. In the painting, she is in the salon of Munkács Castle, accompanied by her children, Ferenc and Julianna, standing before the leaders of the Emperor's army. It is interesting that the French critics did not discuss this painting in any detail, for the subject - as pointed out by Antoinette Ehrard ${ }^{132}$ - was quite popular in France. ${ }^{133}$

At the next Salon in 1863, Madarász exhibited just one work, with the rather uninformative title of Portrait of a Man. Identifying the work would be impossible were it not for a contemporary source that refers to the person portrayed. Although Gautier only mentions the painting in passing, in the form of a rather vague comment, his report on the Salon contains information that has proved to be of immense use to posterity: "[Madarász] exhibited only one portrait this year, with proud and upright bearing, as picturesque in costume as it is characteristic in physiognomy. He did not have to search too far for his model." ${ }^{34}$ This brief sentence allows to infer that the portrait was of the artist himself, and the date clearly indicates that it was an early self-portrait, executed in 1863 (Fig. 1). 135

In 1864 Madarász exhibited one history painting and one portrait at the Salon. The portrait was of the author of a famous work on Attila the Hun, ${ }^{136}$ the historian Amédée Thierry (1797-1873), ${ }^{137}$ who described Attila not only as a barbarian prince but also an outstanding ruler (Fig. 20). Thierry's work was translated into Hungarian just three years after it was published. Madarász gave the portrait to the Hungarian Academy of Sciences. Gautier - who was apparently keeping a close eye on Madarász's appearances at the Salon rhapsodised about the painting, calling it "... a very fine piece. It is distinguished by confident drawing, honest colours and a masterly quality that turns the portrait

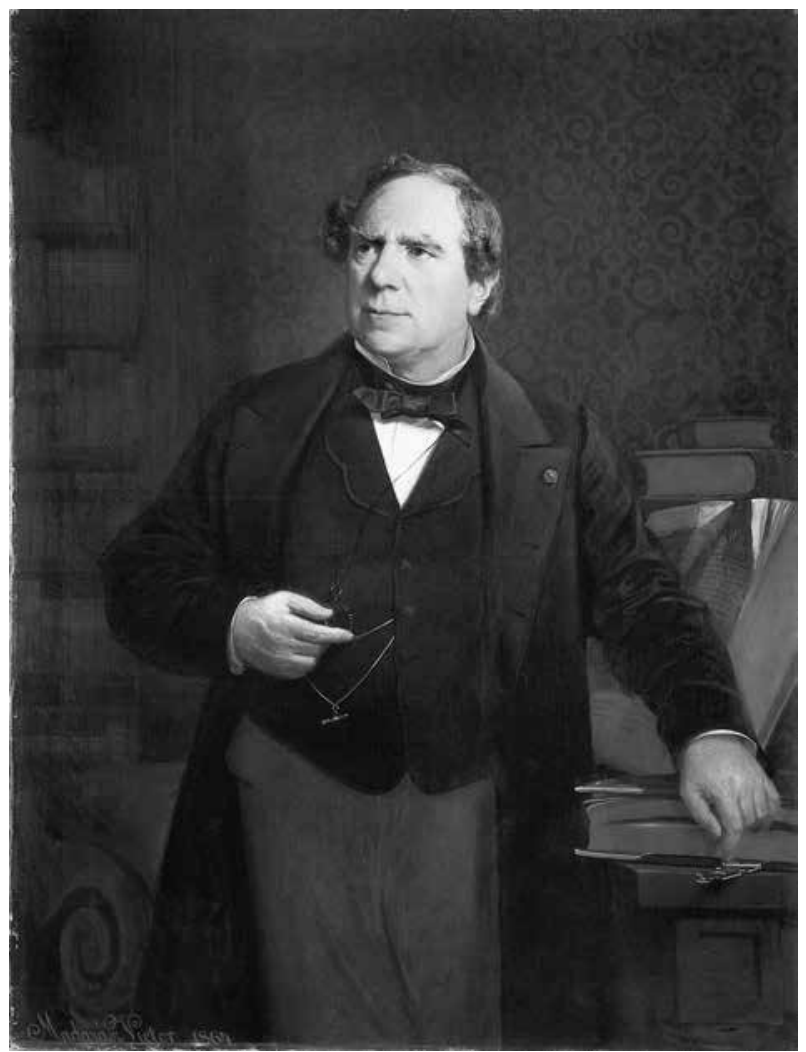

Fig. 20. Viktor Madarász: Portrait of Amédée Thierry, 1864; oil on canvas, $123 \times 98 \mathrm{~cm}$; Art Collection of the Hungarian Academy of Sciences, Budapest, inv. no. 477

(C) MTA Mưvészeti Gyứjtemény / Szelényi Károly)

into a painting". ${ }^{138}$ He also writes at length about the historical painting on display, Zrinyi and Frangepán in Wiener Neustadt Prison (Fig. 21). After repeating the catalogue description verbatim, so that viewers would have an idea about the historical background to the event depicted - common practice among critics writing about the Salon -, he embarks on a psychologising yet not entirely accurate description of the painting, reserving his praise for the end: "In this scene, Madarász has succeeded in joining dramatic interest with pictorial interest. The subject has not made him forget about art. He has deployed great skill at light and shade and has done an excellent job on the noblemen and elegant attire of Hungary."139 Madarász was also praised for his use of light and his measured chiaroscuro by Louis Auvray, director of Revue artistique: "The semi-shaded portrayal in Madarász's picture is well executed and matches the drama in the scene. In the shade, the head of the younger condemned man is infinitely expressive, while the light and shade are rendered very effectively." 140 The way in which the artist painted the figures against the backlighting was a true demonstration of his virtuoso technique. 


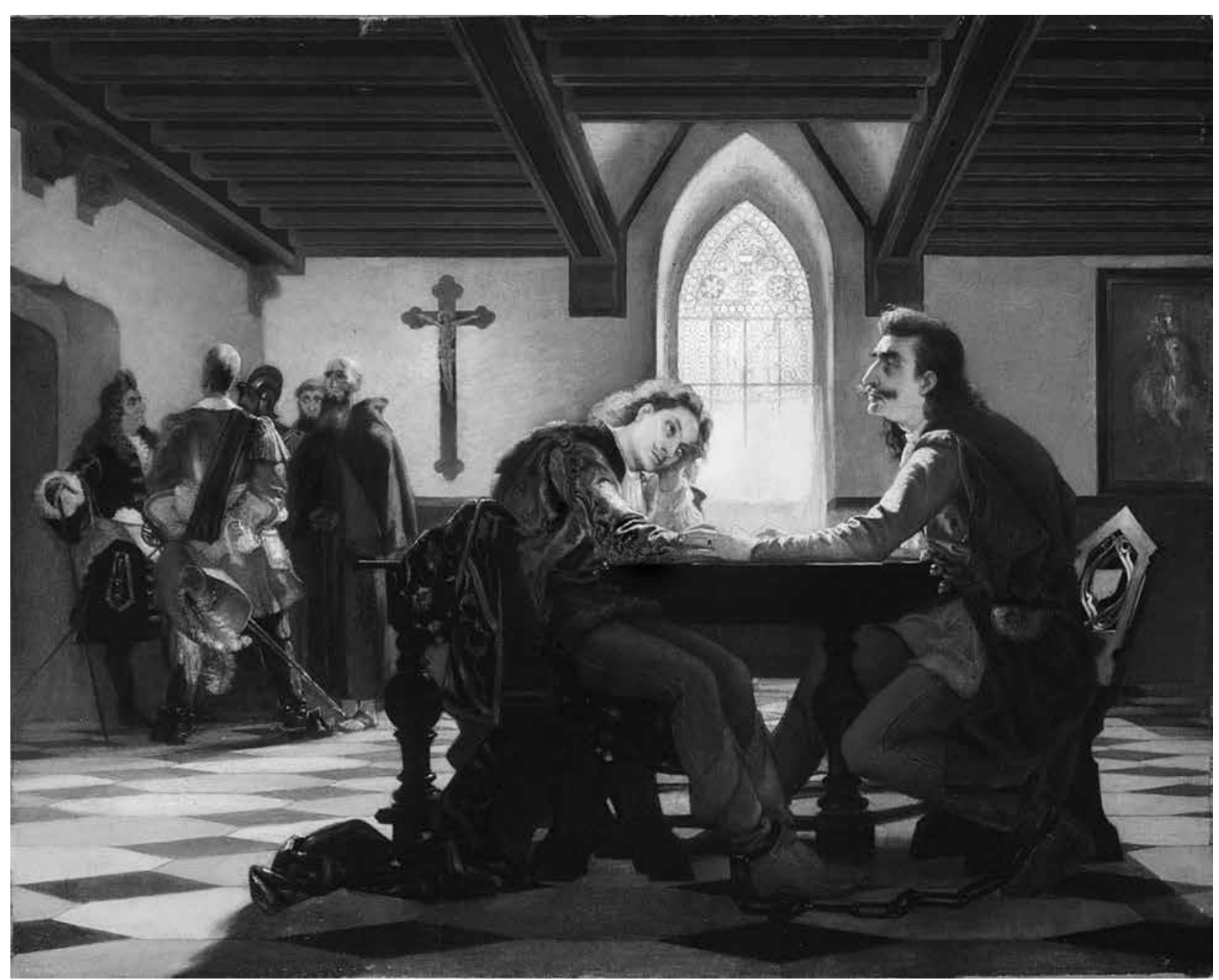

Fig. 21. Viktor Madarász: Péter Zrínyi and Ferenc Kristóf Frangepán in Wiener Neustadt Prison, 1864; oil on canvas, $177 \times 237 \mathrm{~cm}$; Hungarian National Gallery, Budapest, inv. no. 2794

(C Szépmúvészeti Múzeum - Magyar Nemzeti Galéria)

1866 was an important year for Madarász, for it marked the second - and last - occasion when he received some kind of "official" recognition - five years after receiving the third-class medal -, even greater than the plaudits offered by the critics: one of his paintings was purchased by the French state. The Ministère de la Maison de l'Empereur et des Beaux-Arts paid 1000 francs for a painting titled Christ on the Mount of Olives ${ }^{141}$ for the Église Saint-Caprais in the Gironde department, where it is still kept as an altar painting (Fig. 17). The presumable conditions of this purchase have already been discussed. Around a decade and a half later, in 1880 Madarász revisited the same theme, painting a different composition for the Lutheran Church in the southern Hungarian city of Pécs. ${ }^{142}$

In the following years, carrying on what had by now become a tradition for him, Madarász continued to exhibit history paintings and portraits of historic figures at the Salon. Dózsa's People (Fig. 22), ${ }^{143}$ depicting an episode (albeit one known only from stories) from the failed Peasants' Revolt of 1514, led by György Dózsa, was submitted to the Salon of 1868. The subject was not a new one for the painter, who had exhibited a portrait of György Dózsa the previous year (Fig. 23). ${ }^{144}$ According to Nóra Veszprémi, ${ }^{145}$ Dózsa's People deviates from the classical conventions of history painting, for the event is not recorded in the chronicles and is not even of cardinal significance. Instead of the deed of a hero, Madarász painted the heroic deed of a group of unknown people: under cover of the night, a few survivors from the bloody end to the revolt have returned to the gallows to remove the body of one of their companions. It is worth noting that, whereas peasants in Hungarian painting regularly appeared in genre pieces, Madarász elevated them to the rank of historical heroes. In Madarász's 


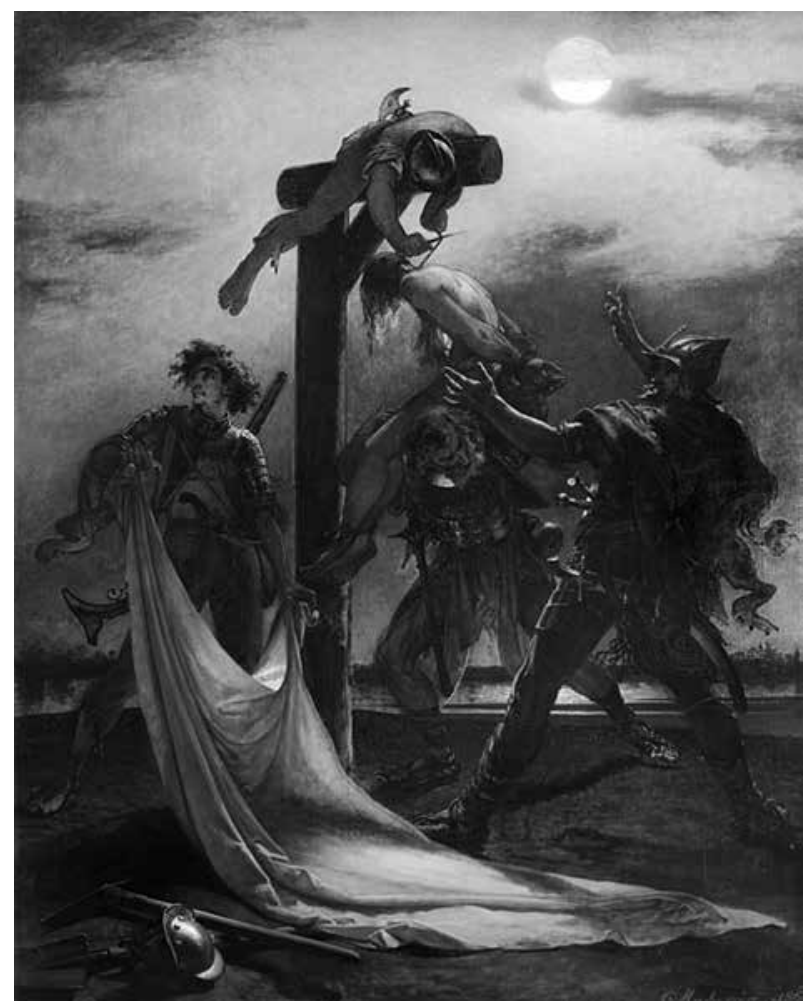

Fig. 22. Viktor Madarász: Dózsa’s People, 1868; oil on canvas, $164 \times 130 \mathrm{~cm}$;

Hungarian National Gallery, Budapest, inv. no. 54.324

( Szépmúvészeti Múzeum - Magyar Nemzeti Galéria)

paintings, we can often see him "raise a scene known only from hearsay to the status of history, rather like Paul Delaroche". ${ }^{146}$ Here, Madarász selected a composition that was filled with allusions, as he had with the Mourning of László Hunyadi, facilitating an allegorical interpretation: by referring to the iconography of the Deposition of Christ, the composition draws a parallel between the solidarity of the peasants towards their executed kin and the loyalty to Jesus shown by his disciples.

Madarász never exhibited this painting in Hungary. After the Compromise of 1867 (and right up until the end of the century), paintings with rebellious or anti-Habsburg motives and works that suggested republican or plebeian sentiments were not welcomed at Hungarian exhibitions. ${ }^{147}$ According to Katalin Sinkó, ${ }^{148}$ Madarász may have painted this work with a Parisian audience in mind, for the French capital was on the brink of revolution at the time. ${ }^{149}$ The painter may have thought that the French still recalled the uprisings of 1830 and 1848, and would therefore understand the relevance of the painting. If they did, this was not reflected in the reviews. As far as we know, the only critic to spare more than a brief

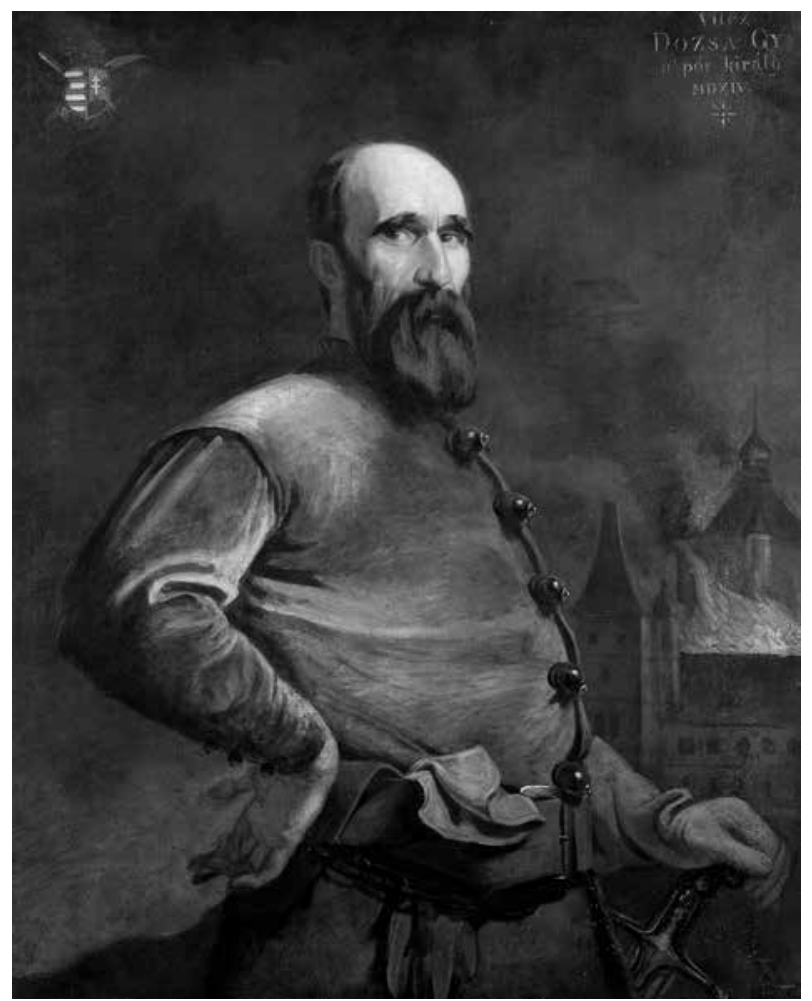

Fig. 23. Viktor Madarász: György Dózsa, 1867; oil on canvas, $123 \times 98 \mathrm{~cm}$; Kiscelli Museum - Municipal Gallery, Budapest, inv. no. 75.38

(ㄷ) BTM Fôvárosi Képtár / Bakos Ágnes - Tihanyi Bence)

sentence for this work was Gautier: "Dózsa's People ... does not deal with a very pleasant subject, but the sinister group produces a fantastic effect, which recalls the gallows of the old king of the Bohemians in the tale about Isabelle of Egypt by Achim von Arnim." 150

The end of the 1860s also marked the end of Viktor Madarász's appearances at the Salon de Paris. He was awarded no further prizes or official commissions, and he sold no further works. At his last Salon, in 1869, all he exhibited was a portrait of a lady; he subsequently returned to Hungary. The following year he entered a history painting competition organised by the Hungarian state, submitting a draft for a work titled Gábor Bethlen among his Scholars, which earned him second prize. ${ }^{151}$ The paintings he produced in Hungary were received with ever diminishing approval, although in 1873 he was among the painters chosen to represent Hungarian art at the Vienna World's Fair. That same year, following the death of his father, he took over the running of the family ironmongery business, and since the critics had begun to take away his motivation, he painted less and less, abandoning his brushes completely around 1880 . He only took up painting again some twenty years later, but neither the quality of his 
paintings nor their reception could match the dizzy heights of his youth.

There can be no doubt that Paris and the Salon played an extremely important part in the art of Viktor Madarász, for it was there that he painted and exhibited his most important works. The impact that the Parisian artistic environment - e. g. its museums, the École des Beaux-Arts, Cogniet's private atelier and French history painting in general - had on the art of Madarász should not be underestimated, nor should the importance of Léon Cogniet and Théophile Gautier. Appreciating his talent as well as his prepossessing nature, these two men shaped the artistic career of the painter in several ways, helping him earn a reputation and a living, often by leveraging their connections in his interest.

Furthermore, by settling in Paris, Madarász was able to express his opinion in his works more firmly and to paint more freely than he could have done in Hungary at the time, where the social and political situation was far from favourable. Paradoxically, the anointed painter of Hungarian national romanticism had to go abroad to paint the pictures that would promote the national consciousness in an oppressed country and champion the ideals of Hungarian independence. Even more contradictory than this is the fact that after his return to Hungary he was hardly appreciated at all, and eventually ignored. His homecoming ended in failure. Despite the positive change in the national mood, the success he had anticipated was not forthcoming. As the art critic and historian Zoltán Farkas (1880-1969) considered it in the columns of Nyugat magazine in 1930, on the centenary of the artist's birth: "His career was one of the most unfortunate of any Hungarian artist [...]. Madarász became so attached to the painterly culture of Paris that when he became separated from it, his creativity became uncertain and forceless." 152 Time took its toll both on the man and his art, and his paintings no longer attained the high standards set by the works he had painted in his prime. As Dénes Radocsay put it, "he became a silent artist, and was more of a national relic that had come from Paris than a factor still with the capacity to shape the direction of his nation's art." 153 It appears that in his own age he was more popular in France than in his homeland. "No one is a prophet in his own country," goes the old adage, and this certainly applied to Viktor Madarász, who must have felt it himself; as he wrote a few years before his death, "Paris at the time welcomed me, even though I was foreign, and also for that very reason. And the more Hungarian I was, the more I was respected. [...] I was appreciated there, and loved by the leaders of French intellectual life: Dumas the Elder and the Younger, and Théophile Gautier, and Victor Hugo, and Baudelaire and tutti quanti..."154

\section{APPENDIX}

\section{LIST OF WORKS BY VIKTOR MADARÁSZ EXHIBITED AT THE SALON DE PARIS (1861-1869)}

1 - The present catalogue was compiled on the basis of the original Salon catalogues. All the information is presented here in the form included in the archive catalogues. See SANCHEZ, LobSTEIN and SEYdoux 2004, SANCHEZ, LobSTEIN and Seydoux 2005a, Sanchez, Lobstein and Seydoux 2005b. 2 - The numbers preceding the titles of the works are the original Salon catalogue numbers.

3 - "Méd. 3e cl." signifies a 3rd class medal, and "[EX.]" or "Exempt" in turn that the artist was free from the preselection by the jury, which was customary for artists who were past recipients of a medal.

\section{1}

MADARASZ (VICTOR DE), né à Csetnek (Hongrie), élève de M. Léon Cogniet.

Rue Durantin prolongée, 2 (Montmartre).

2061 - Ladislaw Hunyady, frere de Mathias Corvin, décapité par ordre de Ladislas V, roi de Hongrie

[See Fig. 11.]

2062 - Félicien Zach. Il a recu de sa fille la révélation des violences dont elle a été victime de la part de Casimir, beaufrere de Charles d'Anjou, roi de Hongrie, 1332.

[See Fig. 18.]
2063 - Helene Zrinyi, femme du comte Toekoely, chef de l'insurrection hongroise en 1688, trahie par son secrétaire, signe la capitulation du chateau de Munkats, apres une défense de deux ans contre les troupes de l'empereur Léopold I.

[See Fig. 19.]

\section{3}

MADARASZ (VICTOR DE), né á Esetnek [sic] (Hongrie), éleve de M. L. Cogniet.

Méd. $3^{\mathrm{e}} \mathrm{cl}$. (Histoire) 1861.

Rue Fontaine-Saint-Georges, 38 bis

1246 - Portrait d'homme.

[See Fig. 1.]

\section{4}

MADARASZ (VICTOR DE), né à Csetnek (Hongrie), élève de M. L. Cogniet.

Méd. $3^{e} \mathrm{cl}$. (Genre historique) 1861 - [EX.]

Rue Fontaine-Saint-Georges, 38 bis

1268 - Entrevue des comtes Pierre Zriny et François Frangepan avant leur exécution à Neustadt. 
Ayant pris part à une conjuration qui avait pour but le rétablissement des droits constiĺĺtutionnels de la Hongrie, ils furent traduits devant un tribunal autrichien, condamnés à mort et exécutés le 30 mars 1671.

[See Fig. 21.]

1269 - Portrait de M. A. Thierry, sénateur. (Appartient à l'Académie Hongroise de Pesth.) [See Fig. 20.]

\section{5}

MADARASZ (VICTOR DE), né à Csetnek (Hongrie, empire d'Autriche), élève de M. L. Cogniet.

Méd. $3^{e} \mathrm{cl}$. (Genre historique) 1861

Rue Fontaine, 38 bis.

1412 - L'Évocation.

(Henri HeIne, L'Évocation)

\section{6}

MADARASZ (VICTOR DE), né à Csetnek (Hongrie, empire d'Autriche), élève de M. L. Cogniet.

Méd. 3e cl. (Genre historique) 1861.

Rue Durantin, 14 (Montmartre).

1284 - Le Christ au Jardin des Oliviers.

[See Fig. 17.]

\section{7}

MADARASZ (VICTOR DE), né à Csetnek (Hongrie, empire d'Autriche), élève de M. L. Cogniet.

Méd. 3e cl. 1861.
Rue Durantin, 14 (Montmartre).

1010 - La comtesse Blanca Teléki et Mlle Clara L..., condamnées à dix années de réclusion dans le château fort de Kufstein (Tyrol), après les évènements de 1848 et 1849, en Hongrie (Appartient à M. le comte de Teleki).

[See Fig. 8.]

1011 - Portrait de Georges Dózsa [Dózsa], surnommé le Roi des paysans.

[See Fig. 23.]

\section{8}

MADARASZ (VICTOR DE), né à Csetnek (Hongrie), élève de M. L. Cogniet.

Exempt.

Rue Durantin, 14 (Montmartre).

1641 - Le gibet; guerre des paysans en Hongrie (1514).

[See Fig. 22.]

1642 - Dobozy.

Se voyant enveloppé par un détachement turc, après s'être frayé un chemin à travers les avant-postes, pour mettre sa femme en sủreté, il désespère de la sauver et la tue (1526.) [See Fig. 10.]

\section{9}

MADARASZ (VICTOR DE), né à Csetnek (Hongrie), élève de M. L. Cogniet.

Exempt.

Rue Durantin, 14.

1595 - Portrait de $\mathrm{M}^{\text {me }} \mathrm{R} .$.

\section{BIBLIOGRAPHY}

Allard 2007 - Allard, Sébastien: Quelques réflexions sur Paul Delaroche et son influence en Europe, in Les Artistes étrangers à Paris de la fin du Moyen Âge aux années 1920. Actes des journées d'études organisées par le Centre André Chastel les 15 et 16 décembre 2005, éd. par Chaudonneret, Marie-Claude, Bern: Peter Lang, 2007, 193-202.

Archives Parlementaires [1889] - Archives Parlementaires de 1787 à 1860, lère série, t. XXIX (29 juillet-27 août 1791), Paris: Paul Dupont, [1889].

Auvray [1864] - Auvray, Louis: Exposition des beaux-arts: Salon de 1864, Paris: A. Lévy fils, 1863 [sic].

Az Ujság 1910 - A nyolcvanéves Madarász. Látogatás a jubiláló festômunvésznél, Az Ujság, 1910. december 11., 6-7.

BAKÓ 2009 - BAKÓ, Zsuzsanna: Történelmi festészetünk és a müncheni akadémia, in München magyarul. Magyar müvészek Münchenben. Exh. cat. ed. by Szücs, György, Budapest: Magyar Nemzeti Galéria, 2009, 67-83.

BANn 2014 - BAnN, Stephen: Au fil de l'histoire: généalogie des genres 'anecdotique' et 'historique', in BANN and PaCCOUd 2014, 12-25.

Bann and Paccoud 2014 - L'Invention du Passé. Histoires de coeur et d'épée en Europe 1802-1850. Exh. cat. ed. by Bann, Stephen and Paccoud, Stéphane, Lyon and Paris, Musée des Beaux-Arts and Hazan, 2014.

Benjamin 1968 - Benjamin, Walter: Paris, capital of the 19th century, New Left Review vol. I, no. 48 (1968 MarchApril): 77-88.
Berzeviczy 1925 - Berzeviczy, Albert: Az ötvenes évek képzômúvészete, Magyar Múvészet 1 (1925): 497-523.

BlaskónÉ MajKó and SZŐKe 2002 - BlaskónÉ MajKó, Katalin and SzŐKE, Annamária (eds.): A Mintarajztanodától a Képzômüvészeti Fôiskoláig, Budapest: Magyar Képzômû̃vészeti Egyetem, 2002.

BODNÁr 1981 - BODNÁr, Éva: Il salone di Parigi e la pittura ungherese nel secolo XIX, in Saloni, Gallerie, Musei e loro influenza sullo sviluppo dell'arte dei secoli XIX e XX, 95-98. Atti del XXIV Congresso Internazionale di Storia dell'Arte. Vol. 7, ed. by Haskell, Francis, Bologna, 1981, 95-98.

BONNET 2006 - BONNET, Alain: L'Enseignement des arts au XIXe siècle. La réforme de l'École des beaux-arts de 1863 et la fin du modèle académique, Rennes: Presses universitaires de Rennes, 2006.

Boros 2005 - Boros, Judit: A Hungarian Painter in Paris. Mihály Munkácsy's career between 1870 and 1896, in Munkácsy in the World. Exh. cat. ed. by GoszTonyI, Ferenc, Budapest: Szemimpex Kft. - Hungarian National Gallery, 2005, 33-60.

Boros 2010 - Boros, Judit: Valószerúség és színházi hatás. Gondolatok a színház és a modern/nemzeti történelmi képtípus kapcsolatáról, in KIRÁLY, RÓKA, and VEsZPRÉMI 2010, 261-69.

Boulllo 2009 - Bouillo, Eva: Le Salon de 1827: Classique ou romantique? Rennes: Presses universitaires de Rennes, 2009. 
BRUCKNER 1923 - BRUCKNER, Győző: Madarász Viktor mûvészete történelmi megvilágitásban, Pécs: Dunántúl Könyvkiadó, 1923.

BUSQUET 1859 - BUSQUET, Alfred: Les étrangers à l'Exposition des Beaux-Arts, La Patrie, 11 July 1859.

Callias 1861 - Callias, Hector de: Salon de 1861. Les lettres K. L. M. N. O. P., L’Artiste, vol. 31, nouvelle série, t. XII, no. 12, 1 July $1861,1-11$.

Catalogue des tableaux... 1873 - Catalogue des tableaux, aquarelles, dessins, gravures, eaux-fortes, lithographies, photographies, etc. bronzes et objets d'art composant la collection de Théophile Gautier, Vente Hôtel Drouot, 14-16 janvier 1873, Paris, 1873.

CAZĖs 2012 - CAZĖs, Laurent: L'Image équivoque de l'artiste étranger dans la critique de Salon, in Image de l'artiste, eds. Darragon, Éric and Tillier, Bertrand. Territoires contemporains, nouvelle série - 4, 2012.

Claudon 1999 - Claudon, Francis: Az 1848-as Magyarország és franciaországi megítélése, in CSÉVE 1999, 55-64.

Correspondance générale [1985-2000] - GAUTIER, Théophile: Correspondance générale, 12 tomes, éd. par LACOSTE-VEYSSEYRE, Claudine, Genève: Librairie Droz, 1985-2000.

Csapláros 1935 - Csapláros, István: Théophile Gautier és a magyarok, Pécs: Kultúra Könyvnyomdai Múintézet nyomtatása, 1935

CSÉve 1999 - Nemzeti romantika és európai identitás. Tanulmányok a romantikáról, ed. by Cséve, Anna, Budapest: Petôfi Irodalmi Múzeum és Kortárs Irodalmi Központ, 1999. A Petôfi Irodalmi Múzeum könyvei 8.

Du Camp 1865 - Du Camp, Maxime: Le Salon de 1865, Revue des deux mondes, 1 June 1865, 649.

EHRARD 1989 - EhrARD, Antoinette: Théophile Gautier et les peintres hongrois, Cahiers d'Etudes hongroises 1 (1989): 54-74.

Explication des ouvrages...1863 - Explication des ouvrages de peinture, sculpture, gravure, lithographie et architecture des artistes vivants exposés au Palais des Champs-Élysées le 1er mai 1863, Paris: Charles de Mourgues, 1863.

FARKAS 1930 - FARKAS, Zoltán: Szemle. Madarász Viktor centenáriuma, Nyugat vol. XXIII, no. 24 (16 December 1930): 881-882.

FARKAS 1954 - FARKAS, Zoltán: Munkácsy és Sedelmeyer, in A Magyar Múvészettörténeti Munkaközösség Évkönyve 1953, Budapest: KAK, 1954, 607-611.

FÖLDI 2007 - FÖLDI, Eszter: 'Un monstre de génie'. Zichy Mihály és Théophile Gautier, in Zichy Mihály, a „Rajzoló fejedelem”. A szentpétervári Ermitázs és a Magyar Nemzeti Galéria közös kiállitása, Budapest: Magyar Nemzeti Galéria, 2007, 49-66.

FrançoIs and SCHULZE 1998 - FranÇOIS, Étienne and SCHulze, Hagen: Das emotionale Fundament der Nationen, in Mythen der Nationen. Ein europäisches Panorama, ed. by Flacke, Monika, Berlin: Deutsches Historisches Museum, 1998, 17-32.

Gautier 1861 - Gautier, Théophile: Abécédaire du Salon de 1861, Paris, 1861

GaUtier [1905] - Gautier, Judith: Le Collier des jours, le second rang du collier. Souvenirs littéraires, Paris: Félix Juven, s.d. [1905].

Harvey 2005 - Harvey, David: Paris, Capital of Modernity, New York: Routledge, 2005

Huemer 2004 - Huemer, Christian: Charles Sedelmeyer's Theatricality: Art and Speculation in Late 19th-Century
Paris, in Artwork through the Market: The Past and the Present, ed. by BAKOš, Ján, Bratislava: Slovak Academy of Sciences, 2004, 109-124.

KACZIÁNY 1904 - KaCZiáNY, Ödön: Madarász Viktor, Múvészet vol. III, no. 4 (1904): 249-257.

KaKAS 1859 - KaKAS, Márton [JóKAI, Mór]: Kakas Márton a mûtárlatban, Vasárnapi Ujság vol. 6, no. 22 (29 May 1859): 260.

KelP 1928 - KelP, Anna: A XIX. századi magyar festészet viszonya a francia festészethez, [doctoral thesis], Budapest: Globus Nyomdai Mủintézet Részvénytársaság, 1928.

Keserü, Nagy and BeKe 1996 - Keserü, Katalin, Nagy, Gabriella and BEKE, László (eds.): Múcsarnok, Budapest: Múcsarnok, 1996.

KirÁly, RÓKA and VesZPRÉmi 2010 - KirÁly, Erzsébet, RÓKA, Enikô and VeszPrémI, Nóra (eds.): XIX. Nemzet és müvészet. Kép és önkép. Exh. cat., Budapest: Magyar Nemzeti Galéria, 2010.

KRASZNAI 2013 - KRASZNAI, Réka: Magyar festők a párizsi Szalon kiállításain (1852-1880), MA diss. Eötvös Loránd University, Institute for Art History, Budapest, 2013.

KRASZnAi 2014 - KRASZnAI, Réka: Viktor Madarász, La Déploration de László Hunyadi, [analysis], in BANN and PACCOUd 2014, 283-284

KrasZnAi 2017a - KrasznAi, Réka: "The Creative Mastermind". The History of a Cult Image. A Cabinet Exhibition to Mark the Centenary of the Death of Viktor Madarász. Exh. cat. ed. by BorUs, Judit and Kardos, Eszter, Publications of the Hungarian National Gallery 2017/5, Budapest: Szépmúvészeti Múzeum - Magyar Nemzeti Galéria, 2017. URL: https://issuu.com/szepmuveszeti/ docs/madarasz_ko_tet_pdf_02_

KRASZnAi 2017b - KraszNaI, Réka: A Hungarian Painter in the French Capital: The Parisian Career of Viktor Madarász, in KRASZNAI 2017a, 11-82

LACAMBRE 1984 - LACAMBRE, Jean: Un Style international en 1850 : à propos de l'exposition Delaroche, Revue du Louvre et des musées de France nos. 5-6 (1984): 337340.

Lagrange 1861 - Lagrange, Léon: Salon de 1861, Gazette des Beaux-Arts vol. 3, t. X (1861 April): 321-347.

LÁzÁr 1927 - LÁzÁr, Béla: Zichy Mihály élete és mũvészete, Budapest: Athenaeum, 1927.

Lejeune 2003 - Lejeune, Philippe: Az önéletírói paktum, in Önéletírás, élettörténet, napló. Válogatás Philippe Lejeune irásaiból, ed. Z. VARGA, Zoltán, Budapest: L'Harmattan, 2003.

Lemaire 1986 - Lemaire, Gérard-Georges: Le Salon de Diderot à Apollinaire. Esquisses en vue d'une histoire du Salon, Paris: Henri Veyrier, 1986.

Lemaire 2004 - Lemaire, Gérard-Georges: Histoire du Salon de peinture, Paris: Klincksieck, 2004.

LOBSTEIN 2006 - LOBSTEIN, Dominique: Les Salons au XIXe siècle. Paris, capital des arts, Paris: Éditions de La Martinière, 2006.

LYKA 1920 - LYKA, Károly: Madarász Viktor élete és mũvei, Budapest: Pantheon, 1920.

LYKA 1942 - LYKA, Károly: Nemzeti romantika. Magyar müvészet 1850-1867, Budapest: Singer-Wolfner, 1942.

LYKA 1947 - LYKA, Károly: Közönség és müvészet a századvégen, Budapest: Uj Idők Irodalmi Intézet, 1947. 
LYKA 1951 - LYKA, Károly: Magyar mũvészélet Münchenben 1867-1896, Budapest: Múvelt Nép Könyvkiadó, 1951.

Magnol-Malhache 2007 - Magnol-Malhache, Véronique: Théophile Gautier dans son cadre, Paris: Somogy Éditions d'art, 2007.

MAINGON 2009 - MAINGON, Claire: Le Salon et ses artistes, une histoire des expositions du Roi Soleil aux Artistes Français, Paris: éd. Hermann, 2009.

Mantz 1867 - Mantz, Paul: Les Beaux-Arts à l'Exposition universelle, Gazette des Beaux-Arts, 27 July 1867, 7-30.

MonNier 1995 - MonNier, Gérard: L'Art et ses institutions en France. De la Révolution à nos jours, Paris: Gallimard, 1995.

Noblet 2003 - Noblet, Agnès de: Un Univers d'artistes. Autour de Théophile et de Judith Gautier, Paris: L'Harmattan, 2003.

Ormós 1859 - OrMós, Zsigmond: Adatok a múvészet történetéhez, Pest, 1859.

Paccoud 2014 - Paccoud, Stéphane: 'L'Empereur m'a beaucoup parlé de Delaroche, il a toutes ses gravures'. Succès et diffusion du 'genre historique' en Europe, in BANN and PACCOUD 2014, 92-103.

Pesti Napló 1910 - Madarász Viktor beszámolója, Pesti Napló, 13 February 1910, 20.

Radocsay 1941 - RAdOCSAY, Dénes: Madarász Viktor, Budapest: 1941. Pázmány dolgozatok 67.

RÉVÉSZ 1998 - RÉVÉSz, Emese: Kuruc és labanc - Két testvér - Életrajz Erdély múltjából. Madarász Viktor elsô történeti festménye 1855-ből, Múvészettörténeti Értesítô vol. 47, nos. 1-2 (1998): 141-151.

RÉVÉSZ 2000 - RÉVÉSZ, Emese: A történelem képei a magánélet körében a 19. században; Történeti kép mint sajtóillusztráció 1850-1870, in Történelem-kép 2000, 547-548; 580-597.

RÉVÉSz 2016 - RÉVÉSz, Emese: Kép, sajtó, történelem. Illusztrált sajtó Magyarországon 1850-1870 között, Budapest: Argumentum, 2016.

RÓKA 2014 - RÓKA, Enikő: 'La peinture de genre historique n'existe pas'. Peinture d'histoire et peinture de 'genre historique' en Hongrie au XIXe siècle, in BANN and PACCOUD 2014, 219-227.

Sanchez, Lobstein and Seydoux 2004 - Sanchez, Pierre, Lobstein, Dominique and Seydoux, Xavier eds.: Les Catalogues des salons. VII, 1859-1863, [Reproduction en facsim.] Dijon: L'Échelle de Jacob, 2004.

Sanchez, Lobstein and Seydoux 2005a - Sanchez, Pierre, Lobstein, Dominique and SeYdoux, Xavier eds.: Les Catalogues des salons. VIII, 1864-1867, [Reproduction en facsim.] Dijon: L'Échelle de Jacob, 2005.

SANCHEZ, Lobstein and Seydoux 2005b - SANCHEZ, Pierre, LOBSTEIN, Dominique and Seydoux, Xavier eds.: Les Catalogues des salons. IX, 1868-1870, [Reproduction en facsim.] Dijon: L'Échelle de Jacob, 2005.

SinKó 1983 - Sinkó, Katalin: A nemzeti emlékmú és a nemzeti tudat változásai, Mũvészettörténeti Értesítô vol. 32, no. 4 (1983): 185-201.

SinKó 1986 - SinKÓ, Katalin: A profán történeti festészet Bécsben és Pest-Budán 1830-1870 között, Mũvészettörténeti Értesítô vol. 35, nos. 3-4 (1986): 95-132.
SINKÓ 1995 - SINKÓ, Katalin: Madarász Viktor: Hunyadi László (cat. II.2.4.), in Aranyérmek, ezüstkoszorúk: müvészkultusz és müpártolás Magyarországon a 19. században. Exh. cat., Budapest: Magyar Nemzeti Galéria, 1995, 244-245.

Sinkó 2000a - Sinkó, Katalin: A nemzeti szenvedéstörténet képei, in Történelem-kép 2000, 598.

Sinkó 2000b - Sinkó, Katalin: Dózsa népe, in Történelemkép 2000, 612.

SinKó 2000c - SinKÓ, Katalin: Zách Felicián, in Történelemkép 2000, 606.

SỐTÉR 1941 - SÓTÉR, István: Francia-magyar müvelödési kapcsolatok, Budapest: Magyar Szemle Társaság, 1941.

SZÉKELY 1954 - SzÉKELY, Zoltán: Madarász Viktor, Budapest: A Képzőmúvészeti Alap kiadóvállalata, 1954.

Szívós 2006 - Szívós, Erika: Bohém, polgár, értelmiségi? A magyar képzőmûvészek társadalmi helyzete a századfordulón, in Zsombékok. Középosztály és iskoláztatás Magyarországon, ed. Kövér, György, Budapest: Századvég Kiadó, 2006, 377-416.

Szívós 2009 - Szívós, Erika: A magyar képzômüvészet társadalomtörténete 1867-1918, Budapest, ÚMK, 2009.

Szvoboda Dománszky 2007 - Szvoboda Dománszky, Gabriella: A Pesti Múegylet története. A képzômüvészeti nyilvánosság kezdetei a XIX. században Pest-Budán, [Miskolc:] A Miskolci Egyetem Kiadója, 2007.

ThIERry 1856 - THIERry, Amédée: Histoire d'Attila, de ses fils et successeurs jusqu'à l'établissement des Hongrois en Europe, 1856. Hungarian edition: Attila, Attila fiai és utódai történelme a magyarok Európába telepedéséig. 3rd rev. ed. Pest, 1865. Transl. SzABÓ, Károly.

THIESSE 1999 - THIESSE, Anne-Marie: La création des identités nationales, Europe XVIIIe-XXe siècles, Paris: Éditions du Seuil, 1999

THORÉ 1870 - THORÉ, Théophile: Salons de W. Burger, 1861 à 1868, avec une préface par T. THORÉ, Paris: Renouard, 1870. Vol. II.

Történelem-kép 2000 - Történelem-kép. Szemelvények múlt és mũvészet kapcsolatából Magyarországon, eds. Mikó, Árpád and SinKó, Katalin. Exh. cat., Budapest: Magyar Nemzeti Galéria, 2000.

VAISSE and Kearns 2010 - VAisse, Pierre and Kearns, James: "Ce Salon à quoi tout se ramène": Le Salon de peinture et de sculpture, 1791-1890, Oxford and Berne: Peter Lang International Academic Publishers, 2010.

Vasárnapi Ujság 1861a - Vasárnapi Ujság vol. VIII, no. 29 (21 July 1861).

Vasárnapi Ujság 1861b - Vasárnapi Ujság vol. VIII, no. 48 (1 December 1861).

Vasárnapi Ujság 1879 - Vasárnapi Ujság vol. XXVI, no. 31 (3 August 1879).

Vasárnapi Ujság 1881 - Vasárnapi Ujság vol. XXVIII, no. 2 (16 January 1881).

VESZPRÉmI 2014 - VeszPrÉmi, Nóra: Madarász Viktor, Budapest: Kossuth Kiadó and Magyar Nemzeti Galéria, 2014.

Wilson 2002 - Wilson, Sarah: Paris: Capital of the Arts, 1900-1968, London: Royal Academy of Arts, 2002. 


\section{NOTES}

${ }^{1}$ This paper is the revised and extended version of the study published in the catalogue of the exhibition which marked the centenary of the death of Viktor Madarász: "The Creative Mastermind". The History of a Cult Image, 19 October 2017 - 18 February 2018, Hungarian National Gallery. KRASZNAI 2017b.

${ }^{2}$ For the art historical aspects of nineteenth-century Hungarian nation-building and national identity, see KIRÁLY, RÓKA, and VeszPrÉmi 2010. For similar international trends, see THIESSE 1999.

${ }^{3}$ KirÁly, RÓKA and VeSZPRÉmi 2010.

${ }^{4}$ The social history of nineteenth-century Hungarian art is an area that has been only partially researched. Any studies or other writings that have been published on the topic relate almost exclusively to the social history of Hungarian art in Hungary. But even apart from the important gap-filling study, the book by Erika Szívós - which deals with the institutional, cultural and social historical aspects of the art scene in Hungary -, no other comprehensive work on this topic yet exists (Szívós 2006; Szívós 2009). Aside from this, only a few monographs have covered the history of nineteenth-century art institutions, outlining the operations of certain exhibition locations (the Pest Art Society, Múcsarnok [Art Hall]) and educational establishments (notably the Hungarian Royal Drawing School [Mintarajztanoda], the predecessor to the Hungarian University of Fine Arts (Szvoboda Dománszky 2007; Keserü, Nagy and BeKe 1996; BlasKÓNÉ MAJKÓ and SzŐKE 2002). It is important to mention the work of Károly Lyka (1869-1965): although his writings are, in many respects, now outdated, he was the last art writer to deal with the social aspects of Hungarian art, not only in Hungary itself, but also abroad (LYKA 1947; LYKA 1951). For the connections between Mihály Munkácsy and Charles Sedelmeyer, see FARKAS 1954; Huemer 2004; BOROS 2005, 47-50.

${ }^{5}$ BENJAMin 1968.

${ }^{6}$ HARVEY 2005.

${ }^{7}$ WILSON 2002.

8 See SÓTÉr 1941.

${ }^{9}$ Claudon 1999, 55-64.

${ }^{10}$ For more about the Salon de Paris, see Lemaire 1986; LEMAIRE 2004; LOBSTEIN 2006; MAINGON 2009.

${ }^{11}$ LEMAIRE 1986, 6.

12 Monnier 1995, 122-133.

13 Ibid., 132.

${ }^{14}$ Vasárnapi Ujság 1879, 491.

15 See VAisse and Kearns 2010.

${ }^{16}$ Vasárnapi Ujság 1881, 43.

17 «Art. $1^{\text {er. }}$ Tous les artistes français ou étrangers, membres ou non de l'Académie de peinture et de sculpture, seront également admis à exposer leurs ouvrages dans la partie du Louvre destinée à cet objet.» [Article 1. Every artist, French or foreign, member of the Academy of Painting and Sculpture or not, will be equally permitted to exhibit their works in the section of the Louvre set aside for this purpose.] Archives Parlementaires [1889], 613.

${ }^{18}$ CAZÈs 2012, note 5.

${ }^{19}$ CAZĖs 2012.

${ }^{20}$ BusQuet 1859.

${ }^{21}$ The play on words comes from THORÉ 1870, 125.

22 The Salon of 1827. See Bouillo 2009, 35.
${ }^{23}$ Explication des ouvrages... 1863, VIII.

${ }^{24}$ Du CAMP 1865, 649.

${ }^{25}$ The only publication that expressly discusses the Hungarian painters who exhibited at the Salon de Paris in the nineteenth century is BODNÁR 1981, 95-98. Since this is the published version of a conference lecture, its extent is severely limited, and therefore its content as well, dealing with the appearances at the Salon of only three painters: Viktor Madarász, Mihály Munkácsy and József Rippl-Rónai. Regarding the content, the author clearly only had access to the sources and literature available in Hungary, as the political situation at the time the article was written made it difficult to conduct research abroad. As this was not possible, Bodnár presented stereotypes that were deeply rooted in Hungarian art history writing, although which undoubtedly came as a revelation to the international art historian community at the end of the 1970s.

${ }^{26}$ KRASZNAI 2013.

${ }^{27}$ The painting he exhibited at the Salon in 1863 is now in a French public collection: Károly Herbsthoffer, L'armurier [At the Armourer], 1861. Oil on wood, $20 \times 24.7 \mathrm{~cm}$, inscribed lower right: Ch. Herbsthoffer Paris 1861. Dieppe, Musée municipal, château-musée, inv. no. M.J. 87-1202.

${ }^{28}$ For a broad study of the subject, see KraszNaI 2013. During the period in question, the following painters exhibited at the Salon de Paris: Gyula Aggházy, Lajos Bruck, Lajos Deák-Ébner, Sándor Fellner, Tivadar Feledi (Flesch), Ignác Frankel (also known as Ferenc Ingomár), Róbert Gschwindt, Károly Herbsthoffer, Lipót Horovitz, Viktor Madarász, Károly Markó (Carlo Marco) the Younger, László Mednyánszky, Géza Mészöly, Mihály Munkácsy, László Paál, Ferenc Paczka, Ágoston (August) Schoefft, János Valentiny and Adolf (Adolphe) Weisz. There was great fluctuation in how often and how long each artist was present in the Salon, as well as in how many works were on display.

${ }^{29}$ This fact was established by István Csapláros in 1935 in his work discussing Théophile Gautier and Hungarian artists, and subsequently overlooked by the professional literature. CSAPLÁROS 1935, 11.

${ }^{30}$ Madarász himself mentioned the prize in a brief biography he wrote to Károly Lyka: "In 1861 at the exhibition of the Paris Salon Annuel I earned a gold medal for paintings with a Hungarian historical theme." See LYKA 1920, 4. The same information is contained in the 1954 monography by Zoltán Székely, who even refers to it as a "gold medal of honour of the French state". SzÉKELY 1954, 27.

${ }^{31}$ Among the written Hungarian sources (press, literature, etc.), only the contemporary report in Vasárnapi Ujság correctly identifies the prize he won: "Viktor Madarász, the noted painter compatriot of ours, at the Paris art exhibition, to where we are informed he submitted four [sic] paintings, has won a medal of the third class." Vasárnapi Ujság 1861a, 346.

32 The system of prizes changed several times in the history of the Salon. Until 1863, there were three classes of medal: first, second and third. Each year, the rules of the exhibition stipulated the maximum number of medals that the jury could bestow upon artists in each class, as well as the value of the medals. In 1861 they awarded 6 first-class medals (worth 1500 francs each), 12 second-class medals (500 francs) and 16 third-class medals (250 francs); Madarász was awarded one of the latter. The system was differ- 
ent between 1863 and 1870, when there was just one type of medal (médaille unique), 40 of which were awarded each year. (In 1870 Mihály Munkácsy received one such medal.) In 1872 they reverted to the former system of different classes. The awards ceremony was a formal event at the end of each Salon, and the list of medals and recipients was always published in the catalogue of the following year.

33 See LYKA 1942; CSÉVE 1999.

${ }^{34}$ BANN 2014, 12-25.

35 "Delaroche was certainly the first to transform this lesser hybrid genre into a current in painting that eventually spread throughout the world." Ibid., 24.

36 See also LaCAmbre 1984, 337-340; Allard 2007, 193202; PACCOUd 2014, 92-103.

37 BANN 2014, 13.

38 PACCOUD 2014, 95.

${ }^{39}$ Louis Gallait, Derniers honneurs rendus aux comtes d'Egmont et de Hornes, 1851, oil on canvas, $230 \times 328 \mathrm{~cm}$. Tournai, Musée des Beaux-Arts, inv. no. 71/246.

40 Viktor Madarász, Kuruc and Labanc, 1855, oil on canvas, $256 \times 300 \mathrm{~cm}$, inscribed lower right: Madarász Victor 1855 . Owned by the Herend Porcelaine Manufactory, presently on long-term loan to the Hungarian National Gallery, Budapest.

${ }^{41}$ For the painting and its reception see RÉVÉsz 1998.

42 Ormós 1859, 230-231. Cited in RóKA 2014.

43 RADOCSAY 1941.

44 SZÉKelY 1954.

${ }^{45}$ LYKA 1920, 7

${ }^{46}$ At the time, the provisions in the founding regulations of the École des Beaux-Arts, formulated in 1839, were still in force, and would remain so until the school was reformed in 1863.

47 BONNET 2006.

${ }^{48}$ Viktor Madarász's dossier in the student records of the École des Beaux-Arts, inv. no. AJ/52/265; his name appears under registration number 4124 .

${ }^{49}$ According to the questionnaire completed by Viktor Madarász about his life and career for the Lexicon of Hungarian Artists, compiled by Gyula Szentiványi. Hungarian National Gallery Archives, inv. no.: M.M.A. 1065/1920.

50 Viktor Madarász, Convolutum with Ten Sheets, pencil and charcoal on paper, $460 \times 330 \mathrm{~mm}$. Hungarian National Gallery, Budapest, inv. nos. f 71.90 and f 71.91/1-9.

${ }^{51}$ Interestingly, Georges Seurat (1859-1891), the father of neoimpressionism, used this same type of paper, manufactured especially for use by artists.

52 Léon Cogniet, Briseis Mourning the Corpse of Patroclus (Briséis pleurant Patrocle), 1815, oil on canvas, $113 \times 146 \mathrm{~cm}$, Ville d'Orléans, Musée des Beaux-Arts, inv. no. 202.

${ }^{53}$ Viktor Madarász, The Mourning of László Hunyadi, 1859, oil on canvas, $243 \times 311,5 \mathrm{~cm}$, inscribed lower right: MADARÁSZ VICTOR PÁRISBAN 1859, Hungarian National Gallery, Budapest, inv. no. 2800.

${ }^{54}$ BONNET 2006, 128.

${ }^{55}$ Report by Viktor Madarász: Pesti Napló 1910, 20.

56 KelP 1928, 31. Furthermore, a watercolor by Léon Cogniet representing Blanka Teleki used to be in the Ernst Museum of Budapest.

${ }^{57}$ An account of this story can also be found in Az Ujság 1910, 7.

58 Viktor Madarász, Countess Blanka Teleki and Klára Leövey in Prison at Kufstein, 1867, oil on canvas, $174 \times 241 \mathrm{~cm}$, no inscription. Hungarian National Gallery, Budapest, inv. no. $71.62 \mathrm{~T}$

${ }^{59}$ For the influence exerted by Paul Delaroche on Hungarian history painting, see BAKÓ 2009, 67-83; RÓKA 2014 , 225-227.

${ }^{60}$ Viktor Madarász after Eugène Delacroix, Jewish Wedding in Morocco, between 1856 and 1859, oil on canvas, $38 \times 46.2 \mathrm{~cm}$, Hungarian National Gallery, Budapest, inv. no. 4968

${ }^{61}$ Eugène Delacroix, Jewish Wedding in Morocco, ca. 1839 (exhibited at the 1841 Salon), oil on canvas, $105 \times 140 \mathrm{~cm}$, Louvre, Paris, inv. no. 3825.

62 Based on the catalogues I found detailing the permanent exhibitions at the Musée du Luxembourg, Delacroix's work was definitely on display there between 1847 and 1873. Madarász probably made his copy after his arrival in Paris in 1856 but before he painted the Mourning of László Hunyadi.

${ }^{63}$ The literature on Madarász informs us of three more copies of paintings that he must have made during his studies: Girl in a Fur and The Venus of Urbino by Titian, and Susanna and the Elders by Van Dyck. See "Madarász Viktor múveinek jegyzéke" [List of works by Viktor Madarász], serial nos. 46-49, in RADOCSAY 1941, 77.

${ }^{64}$ Viktor Madarász, Péter Zrínyi and Kristóf Frangepán in Bécsújhely Prison, 1864, oil on canvas, $177 \times 237 \mathrm{~cm}$, inscribed lower right: Madarász Viktor 1864. Hungarian National Gallery, Budapest, inv. no. 2794

${ }^{65}$ Viktor Madarász, Dobozi, 1868, oil on canvas, $116 \times 311.5 \mathrm{~cm}$, inscribed lower left: Madarász Viktor. Hungarian National Gallery, Budapest, inv. no. 59.153 T.

66 See Appendix. "List of works by Viktor Madarász exhibited at the Salon de Paris" in this volume: 275-276.

${ }^{67}$ Gautier was also on very good terms with Mihály Zichy (1827-1906), see Földi 2007, 49-68.

68 See SZÉKELY 1954, 27.

${ }^{69}$ FARKAS 1930.

${ }^{70}$ LYKA 1942

${ }^{71}$ Part of this analysis was published in the catalogue for the exhibition titled L'Invention du Passé: KRAszNaI 2014, 283-284.

72 SinKÓ 2000a, 598; see also SinKó 1986, 95-132.

${ }^{73} \mathrm{~A}$ long line of literary works deal with the story of the beheaded hero: György Bessenyei, Hunyadi László tragédiája, három játékban, versekben [The tragedy of László Hunyadi, in three acts, in verse] (Vienna, 1772); Ádám Pálóczi Horváth, Fogoly Hunyadi [Hunyadi the captive] (1792); Benedek Virág, Hunyadi László. Tragédia [László Hunyadi. A tragedy] (Buda, 1817); Gergely Czuczor, Hunyadi (1833); Lőrinc Tóth, Hunyadi László. Történelmi dráma öt szakaszban [László Hunyadi. Historical drama in five sections] (Pest, 1846); János Arany, V. László [Ladislaus V] (1853). Writers and poets often also turned to the two-volume Matthias Corvinus by Ignác Aurél Fessier (Breslau, 1793-1794) and the "Civic Lexicon" by Ferenc Budai: Magyarország polgári históriájára való lexikon a XV. század végéig [Lexicon of the civic history of Hungary until the end of the 15th century] (Nagyvarad [Oradea, Romania], 1804-1805), 2 vols; second edition: "Budai Ferenc Polgári Lexikona" [The Civic Lexicon of Ferenc Budai] (Pest, 1866), which embellished the story of László Hunyadi with the romantic accoutrements of dramas from the age of chivalry. Around mid-century, artists also had ac- 
cess to two influential historical works: László Szalay's Magyarország története [History of Hungary] (first edition 1853) and József Teleki's three-volume Hunyadiak kora [The age of the Hunyadis] (1853-1856). See SinKó 1995, cat. no. II.2.4., 244-45.

${ }^{74}$ Cf. FRAnCOIS and SCHUlze 1998, 17-32.

${ }^{75}$ Two periodicals (Hölgyfutár and Képes Ujjság) published it as an illustrated page in 1860; see the reproduction of these prints in KRASZNAI 2017a, figs. 14-15, 52-53.

See also RÉVÉSz 2000; RÉVÉSZ 2016.

76 SINKÓ 1983, 191.

77 BeRzEVICZY 1925, 497-523.

78 SINKÓ 2000a, 598

79 See BANn 2014, 24.

${ }^{80} \mathrm{Ibid}, 25$.

${ }^{81}$ Ibid.

82 This was similar to the Belgian counts Egmont and Hornes, who had been made famous at the 1852 Salon in a painting by Louis Gallait (The Last Honours Paid to Counts Egmont and Horn, 1851).

${ }^{83}$ For the dramatic picture type in history painting, see Boros 2010, 263-264.

${ }^{84}$ See the reproduction of these different versions in KRASZNAI 2017a, figs. 17-19 and 21, 56-59.

${ }^{85}$ It was common practice at the time for successful history pictures to be copied and reproduced in smaller versions (reductions). See PACCOUd 2014, 92-103.

${ }^{86} \mathrm{He}$ exhibited two further paintings this year: Felicián Zách and Ilona Zrínyi in Munkács Castle. It is a legitimate question whether the medals up for grabs at the Salon de Paris were awarded for a specific work or perhaps for the sum total of all the works exhibited by an artist in any given year. In the brief biography he wrote for Károly Lyka, Madarász says he received it for "paintings with a Hungarian historical theme" (see LYKA 1920, 4). After 1791, when the Salon was reformed as an institution, every prize was initially bestowed for a specific work, which was clearly stated in reviews and reports. Later, however, the situation became increasingly less clear cut. Although the literature and the press often mentioned that an artist had won a prize at the Salon for a specific work, this is not corroborated by anything in the Salon's regulations, in the list of recipients or related texts, or in any other document pertaining to the Salon. The texts of the awards ceremonies state only that a given painter was judged to be worthy of a prize at a given Salon. In the case of Madarász, for instance, it frequently appears in literature that he was awarded a prize by the Salon for the Mourning of László Hunyadi. However, as he exhibited three works at the exhibition in 1861 , it is only by indirect means that we can deduce precisely which painting would have earned the jury's approval. One paper (Vasárnapi Ujság) named the work titled Ilona Zrinyi in Munkács Castle, but the source of this information is unknown: "Gyózô [translator's note: this is the "original" Hungarian name for "Viktor", and also means "Victor" in everyday parlance] Madarász, our exceptionally talented painter compatriot, has been presented by [Alexandre Colonna] Walewski, on behalf of Emperor Napoleon III, with a gold medal and a diploma appointing him "historical painter", for his work titled "Ilona Zrinyi", exhibited in Paris. An honour so high has never previously been bestowed upon any Hungarian, nor indeed upon any artist from the Austrian Empire." Vasárnapi Ujság 1861b, 574. It is also likely that the jury's intention was not to give a prize for any particular work but to reward the artist himself, or - in the case of the médaille d'honneur - his entire life's work.

${ }^{87}$ According to Ehrard, the caricature of the painting (featured in Salon de 1861. Album caricatural par Galletti, Paris, Librairie Nouvelle, A. Bourdilliar \& C ie Editeur, [1861]), proves how famous it was, for only the most noteworthy works would be rendered in caricature. EHRARD 1989, 56. See the reproduction of the caricature in KRASZNAI 2017a, fig. 20, 57.

88 GAUTIER 1861, 9.

${ }^{89}$ According to Ödön Kacziány: KaCZIÁNY 1904, 249-257.

${ }^{90}$ EHRARD 1989, 56.

${ }^{91}$ EHRARD 1989, 54-74.

92 KaCZiány 1904. The artist described the situation in a similar way when he was interviewed as an old man: "At the Salon de Paris, three of my paintings were exhibited at the same time, the László Hunyadi, the Felicián Zach and the Ilona Zrínyi. To my great pride, I was awarded a gold medal for the Hunyadi. I do not wish to boast, but I was the first artist, not only in Hungary, but in the whole of the Monarchy, to be granted this special honour. This success suddenly brought me recognition in Paris and gained me entry into the most exclusive social circles. I was then invited to Neuilly, to the most famous critic in France, Théophile Gautier. That afternoon I spent in Neuilly opened up a magnificent new horizon. Every Thursday I was a guest at the home of the consul in Neuilly, where the Parisian artistic and literary elite convened." Az Ujság 1910, 7.

93 BRUCKNER 1923, 6; Kelp 1928, 29-30; CSAPLÁRos 1935, 20; RAdocsay 1941, 24; SZÉKely 1954, 20-21; VesZPrÉmI $2014,24$.

${ }^{94}$ GAUTIER [1905]. I would like to take this opportunity to thank Véronique Magnol-Malhache, art historian at the Bibliothèque André-Desguine des Archives départementales des Hauts-de-Seine, for drawing my attention to this important source.

95 LeJEUNE 2003, 18

${ }^{96}$ GAUTIER [1905], 91-96

97 GaUTIER [1905], 271.

98 Théophile Gautier's correspondence was published in a 12-volume critical edition between 1985 and 2000. See Correspondance générale [1985-2000].

${ }^{99}$ For further examples of this, see MagnOL-MalHache 2007.

100 EHRARD 1989, 54. According to Ehrard, Gautier's interest in the Hungarians was matched by only a few other foreign artists, including the German Peter von Cornelius, and the Polish painters Kwiatkowski, Rodakowski and Matejko.

${ }^{101}$ CSAPLÁros 1935, 20. Csapláros makes reference to Béla Lázár (LÁzÁr 1927, 50).

102 GAUTIER [1905], 93.

${ }^{103}$ Probably referring to the French poet and essayist Sully Prudhomme (1839-1907).

104 GaUTIER [1905], 95-96.

105 Cited in Noblet 2003, 289.

106 GAUTIER [1905], 189-190.

107 GAUTIER [1905], 249-253.

108 GAUTIER [1905], 274.

109 GAUTIER [1905], 185-187.

110 Catalogue des tableaux... 1873: no 70: Madarasz (Victor), Mort de Ladislas Huniadi, signé à gauche, 1862, 
$46 \times 56 \mathrm{~cm}$. The Bibliothèque André-Desguine des Archives départementales des Hauts-de-Seine houses the copy of the auction catalogue that once belonged to Étienne Haro, a painter, restorer and merchant who was good friends with Gautier, as well as the expert consultant for the auction. Written in pencil beside most of the lots in this copy are two numbers, presumably the estimated value and the final sale price, and the name of the buyer. Judging from this information, the Hunyadi reduction was estimated at 800 francs, but was sold for just 410 francs, to a buyer named Jacobi. The painting - which I recently identified by the one being today in a Hungarian private collection, thanks to a label on its back - was recently exhibited at the Hungarian National Gallery on the occasion of the cabinet exhibition marking the centenary of the artist's death: "The Creative Mastermind". The History of a Cult Image, 19 October 2017 - 18 February 2018, Hungarian National Gallery. (KRASZNAI 2017a, cat. no. 11.) Viktor Madarász, The Mourning of László Hunyadi (reduction), 1860, oil on canvas, $46 \times 57 \mathrm{~cm}$, inscribed lower right: "Victor de Madarasz Paris. 1860".

${ }^{111}$ He received a painting each from Eugène Delacroix and from Ingres. Gautier thanked the latter in a sonnet published in Le Moniteur Universel. (See MAGNOL-MALHACHE 2007, 56, 58.) He also received a painting from Pierre Puvis de Chavannes (Correspondance générale [1985-2000], Tome VIII, no. 3239, letter dated before 22 May 1864, 298). According to his correspondence, Isidore Pils thanked him for his positive review by sending him a watercolour (Correspondance générale [1985-2000], Tome X, no. 3980, letter dated 20 March 1868, 81). Another letter informs us that the collector Senator Boittelle sent a painting by Diaz to Gautier to express his gratitude for the article about his collection. (Correspondance générale [1985-2000], Tome XII, no. 3559bis, letter dated April 1866, 270-271.)

112 Catalogue des tableaux... 1873: no. 179 : Zichy, Les Déterreurs de morts, signé avec dédicace, 1858, Saint-Pétersbourg, $41 \times 36 \mathrm{~cm}$. The starting price was 500 francs, and it was sold for 800 francs to the same Jacobi who bought the Madarász painting.

113 GAUTIER [1905], 254-255.

114 See Magnol-MalHache 2007.

115 See KRASZNAI 2013.

116 Correspondance générale [1985-2000], Tome VIII, no. 3245 , letter dated 25 May 1864, 303.

117 Ibid., no. 3258, letter dated 2 June 1864, 311.

${ }^{118}$ Correspondance générale [1985-2000], Tome X, no. 3945, letter dated 24 February 1868, 54.

119 See the account by the artist (in Hungarian) in Az Ujság $1910,7$.

${ }^{120}$ Viktor Madarász, Felicián Zách, 1858, oil on canvas, $152 \times 111 \mathrm{~cm}$, inscribed lower right: Madarász Victor Páris 58. Hungarian National Gallery, Budapest, inv. no. 66.14 T.

${ }^{121}$ Viktor Madarász, Ilona Zrinyi in Munkács Castle (Ilona Zrinyi in front of the inquisitor), 1859, oil on canvas, $146.5 \times 185 \mathrm{~cm}$, inscribed lower right: Madarász Viktor Párisban 1859. Hungarian National Gallery, Budapest, inv. no. 2805.

122 KAKAS 1859, 260.

123 Ibid.

124 "[Viktor Madarasz] Exhibited three paintings, each showing the creative mastermind." Napkelet, 29 May 1859, 366.
125 Callias 1861, 7.

126 GAUTIER 1861, 263.

127 Ibid., 264.

${ }^{128}$ The story behind the painting, in brief, goes: Prince Casimir (later King Casimir III of Poland), whilst on a visit to Charles Robert (King Charles I of Hungary), seduces one of his sister's (Queen Elizabeth's) ladies-in-waiting, named Klára Zách. Klára's father, Felicián Zách, later attempts to take out his revenge on the king, but when he fails, almost his entire family is executed. Madarász shows the moment when Klára tells her father what Casimir did to her and the distraught Felicián Zách swears vengeance, setting up the tragic end.

129 LAGRANGE 1861, 342.

130 Revue des deux Mondes 1861, 59. Cited in EHrard 1989, 55.

131 SINKÓ 2000c, 606.

132 EHRARD 1989, 55.

${ }^{133}$ A melodrama by René-Charles Guilbert de Pixérécourt titled Tékéli, ou le siège de Montgatz (Tekeli [in Hungarian: Thököly], or the Siege of Montgatz [in Hungarian: Munkács]) was premiered in 1804, and revived in 1825. In a novel by Pigault-Lebrun titled Les Barons de Felsheim (which was so popular that it was constantly reprinted between 1824 and 1878), one chapter is about the adventures of Thököly.

${ }^{134}$ This review appeared in Le Moniteur Universel. Cited in EHRARD 1989, 57.

135 Viktor Madarász, Self-Portrait, 1863, oil on canvas, $73 \times 59.5 \mathrm{~cm}$, inscribed at right centre: 18 M63 PARIS. Hungarian National Gallery, Budapest, inv. no. 7585.

136 THIERRY 1856.

137 Viktor Madarász, Amédée Thierry, 1864, oil on canvas, $123 \times 98 \mathrm{~cm}$, inscribed lower left: Madarász Viktor 1864 . Budapest, Art Collection of the Hungarian Academy of Sciences, inv. no. 477 . See the reproduction of the painting in KRASZNAI 2017a, fig. 24, 68.

138 Review from Le Moniteur Universel. Cited in EHRARD $1989,57$.

139 Ibid.

140 Auvray [1864], 59.

${ }^{141}$ Viktor Madarász, Christ on the Mount of Olives, 1866. Gironde, Église Saint-Caprais. Archives nationales, inv. F/21/7637 (archive photo of the painting), F/21/159 (proof of purchase, showing the amount), F/21/360 (document showing its location). See the reproduction of the painting in KRASZNAi 2017a, fig. 26, 72.

142 Viktor Madarász, Christ on the Mount of Olives, 1880, $206 \times 112 \mathrm{~cm}$. Lutheran Church, Pécs.

143 Viktor Madarász, Dózsa's People, 1868, oil on canvas, $164 \times 130.5 \mathrm{~cm}$, inscribed lower right: Madarász 1868 . Hungarian National Gallery, Budapest, inv. no. 54.324.

${ }^{144}$ Madarász painted the portrait of György Dózsa in two versions: Viktor Madarász, György Dózsa, 1867, oil on canvas, $123 \times 98 \mathrm{~cm}$, Budapest History Museum - Municipal Picture Gallery, Budapest, inv. no. 75.38. Viktor Madarász, György Dózsa, 1867, oil on canvas, $116 \times 93.7 \mathrm{~cm}$, Timișoara, Romania. It is uncertain which version Madarász exhibited at the Salon de Paris.

145 VESZPRÉMI 2014, 34-36.

146 Paul Mantz's remarks on Józef Simmler's Death of Barbara Radziwitt (1860, oil on canvas, National Museum Warsaw) could also be applied to Madarász. Mantz 1867. 
147 See SinKó 2000a, 598.

148 SiNKÓ 2000b, 612.

149 Revolution finally broke out two years later, in 1870 .

${ }^{150}$ Review from Le Moniteur Universel, 1-2 June 1868. Cited in EHRARD 1989, 58.

${ }^{151}$ Viktor Madarász, Gábor Bethlen among His Scholars, 1870 , oil on canvas, $73.5 \times 106 \mathrm{~cm}$, no inscription. Hungarian National Gallery, Budapest, inv. no. 2732. Today the large version of the painting is in Romania: Viktor Madarász, Gábor Bethlen among His Scholars, 1873, oil on canvas, $224 \times 344 \mathrm{~cm}$, no inscription, Muzeul de Artă din Târgu Mureş, Târgu Mureş, inv. no. MA. 185.

152 FARKAS 1930.

153 Radocsay 1941, 51.

${ }^{154}$ Pesti Napló 1910, 20. 